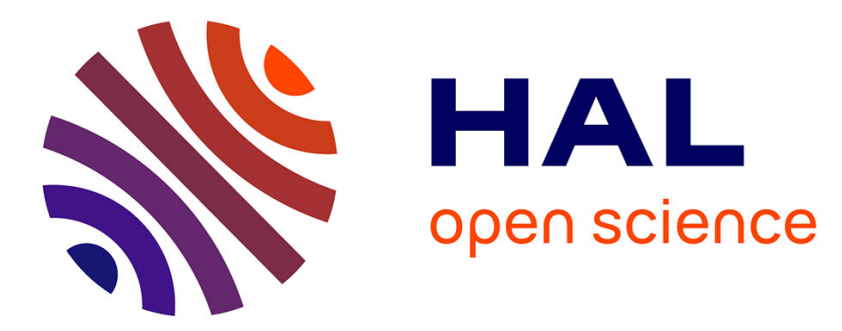

\title{
Analysis of Homotypic Interactions of Lactococcus lactis Pili Using Single-Cell Force Spectroscopy
}

\author{
Ibrahima Dramé, Cécile Formosa-Dague, Marie-Pierre Chapot-Chartier, \\ Jean-Christophe Piard, Mickaël Castelain, Etienne Dague
}

\section{To cite this version:}

Ibrahima Dramé, Cécile Formosa-Dague, Marie-Pierre Chapot-Chartier, Jean-Christophe Piard, Mickaël Castelain, et al.. Analysis of Homotypic Interactions of Lactococcus lactis Pili Using Single-Cell Force Spectroscopy. ACS Applied Materials \& Interfaces, 2020, 12 (19), pp.21411-21423. 10.1021/acsami.0c03069 . hal-02860018

\section{HAL Id: hal-02860018 https://hal.inrae.fr/hal-02860018}

Submitted on 13 Jan 2022

HAL is a multi-disciplinary open access archive for the deposit and dissemination of scientific research documents, whether they are published or not. The documents may come from teaching and research institutions in France or abroad, or from public or private research centers.
L'archive ouverte pluridisciplinaire HAL, est destinée au dépôt et à la diffusion de documents scientifiques de niveau recherche, publiés ou non, émanant des établissements d'enseignement et de recherche français ou étrangers, des laboratoires publics ou privés. 


\section{Analysis of Homotypic Interactions of Lactococcus lactis Pili Using Single-Cell Force Spectroscopy}

Ibrahima Dramé, Cécile Formosa-Dague, Christine Lafforgue, Marie-Pierre Chapot-Chartier, Jean-Christophe Piard, Mickaël Castelain, and Etienne Dague*

Cite This: https://dx.doi.org/10.1021/acsami.0c03069

\section{Read Online}

ACCESS | 岁 Metrics \& More | 回 Article Recommendations | S1 Supporting Information

ABSTRACT: Cell surface proteins of Gram-positive bacteria play crucial roles in their adhesion to abiotic and biotic surfaces. Pili are long and flexible proteinaceous filaments known to enhance bacterial initial adhesion. They promote surface colonization and are thus considered as essential factors in biofilm cohesion. Our hypothesis is that pili mediate interactions between cells and may thereby directly affect biofilm formation. In this study, we use single-cell force spectroscopy (SCFS) to quantify the force of the homotypic pili interactions between individual bacterial cells, using different Lactococcus lactis strains producing pili or not as model bacteria. Moreover the force-distance curves were analyzed to determine the physical and nanomechanical properties of $L$. lactis pili. The results for pili-devoided strains showed a weak adhesion

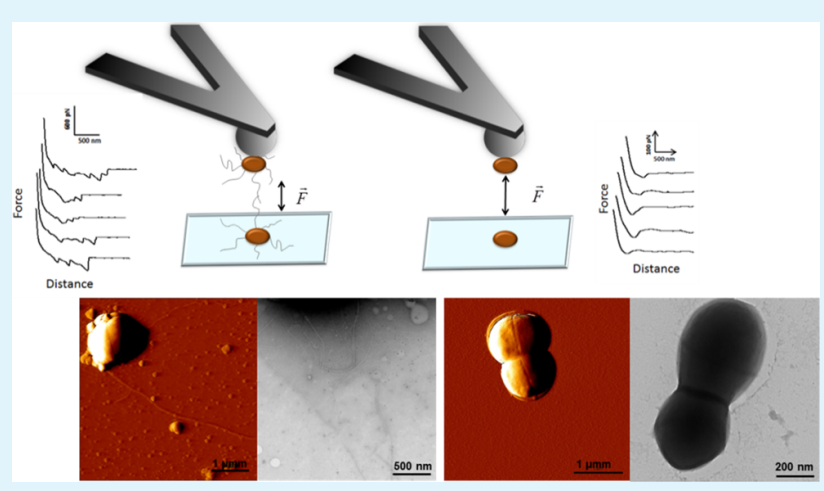
between cells (adhesion forces and work in the range of $100 \mathrm{pN}$ and $7 \times 10^{-18} \mathrm{~J}$, respectively). On the contrary, the piliated strains showed high adhesion levels with adhesion forces and adhesion work over $200 \mathrm{pN}$ and $50 \times 10^{-18} \mathrm{~J}$, respectively. The force-extension curves showed multiple adhesion events, typical of the unfolding of macromolecules. These unfolding force peaks were fitted using the physical worm-like chain model to get fundamental knowledge on the pili nanomechanical properties. In addition, SCFS applied to a L. lactis isolate expressing both pili and mucusbinding protein at its surface and two derivative mutants revealed the capacity of pili to interact with other surface proteins including mucus-binding proteins. This study demonstrates that pili are involved in L. lactis homotypic interactions and thus can influence biofilm structuring.

KEYWORDS: L. lactis, biofilm, pili, SCFS, adhesion force, rupture length, adhesion work

\section{INTRODUCTION}

Pili (Latin for hairs) or fimbriae (Latin for threads) are proteinaceous filaments found at the surface of Gram-negative and positive bacteria. Several roles have been assigned to these proteinaceous structures particularly in the interactions of bacteria with their biotic or abiotic environment. They have been described to be involved in initial bacterial attachment to host tissues to mediate bacterial aggregation and to facilitate colonization and virulence of Gram-negative ${ }^{1-3}$ and Grampositive pathogenic bacteria. ${ }^{4-7}$

Pili in Gram-positive pathogens were first observed in Corynebacterium renale, a pathogenic bacterium responsible of pyelonephritis, using electron microscopy in the $1960 \mathrm{~s}^{8}$ However, while their existence has been known for several decades, their structure and mode of assembly have been characterized at the molecular level more recently. ${ }^{9}$ In contrast to pili of Gram-negative bacteria that are made of noncovalently bound pilins, pili of Gram-positive bacteria are made of pilin subunits that are covalently assembled by a transpeptidase named sortase $\mathrm{C}$ and the resulting polymer is ultimately anchored by sortase A to peptidoglycan in the cell wall. ${ }^{10}$ Similar to what has been observed in Gram-negative bacteria, the presence of pili on the surface of Gram-positive pathogens has been long known to play a key role in the interaction with other proteins in the extracellular matrix, thereby influencing bacterial adhesion and the biofilm structure on biotic surfaces. ${ }^{6,11}$ Pili in nonpathogenic bacteria were discovered more recently in probiotic Lactobacillus rhamnosus $\mathrm{GG},{ }^{12-14}$ in commensal bifidobacteria, ${ }^{15}$ and also in the lactic acid bacterium (LAB) Lactococcus lactis present in various ecological niches such as plants and milk. ${ }^{16}$ In probiotic or commensal bacteria, pili could favor adhesion to the host intestinal mucosa and persistence in the gut. In regard

Received: February 17, 2020

Accepted: April 21, 2020

Published: April 21, 2020 
to L. lactis, in the plant niche, pili could play a role in tissue colonization, while in dairy environment, they could interact with milk components. Moreover, piliated recombinant $L$. lactis might also be more effective to deliver therapeutic proteins in the gut. ${ }^{17-19}$

L. lactis strains contain a chromosome-borne pil operon that encodes a putative sortase $\mathrm{C}(\mathrm{SrtC})$ as well as three putative pilins (PilA, PilB, and PilC). Pili formation was not observed in the laboratory strain L. lactis IL1403 under standard growth conditions; however, overexpression of the pil operon resulted in the synthesis of detectable pili structures (up to $3 \mu \mathrm{m}$ in length with a diameter of $5 \mathrm{~nm}$ ). PilB is the backbone of the pilus, covalently polymerized by the action of sortase $\mathrm{C}$ to form the filamentous structure of the pilus. PilA is the tip protein and PilC is the anchoring protein of the whole structure into the peptidoglycan layer. Mutants of the different proteins encoded by the pil operon from L. lactis IL1403 were then constructed to study the role of each pilus subunit in adhesion and biofilm formation. These investigations notably allowed to understand the role of pili in L. lactis adhesion to abiotic materials (polystyrene, stainless steel) ${ }^{20}$ and in biofilm formation. ${ }^{16}$ The ability of piliated bacteria to stand on polystyrene under flow shear conditions was also studied, and the results showed that pili of L. lactis, and more particularly their backbones, were able to withstand a shear stress of more than $80 \mathrm{~Pa}$, thereby showing their capacity to form strong adhesive bonds on abiotic surfaces. ${ }^{20}$ In another study, optical tweezers were used to analyze the nanomechanical properties of single L. lactis pilus, which allowed to demonstrate that pili are highly flexible and inextensible structures. ${ }^{21}$ Finally, Oxaran et al.'s investigations ${ }^{16}$ demonstrated that pili of L. lactis are involved in the autoaggregation phenotype in liquid cultures and in the biofilm architecture, thus showing their crucial role in biofilm structuration and cell cohesion.

Pili were also characterized in a plant isolate of L. lactis (TIL448) with a backbone pilin (YhgE2) exhibiting 28\% sequence similarity with PilB (YhgE) of L. lactis IL1403. In this strain, pili biosynthesis is encoded on a plasmid and assembly of pili was visualized without overexpression. ${ }^{22}$ These pili were shown to contribute to bacterial adhesion to epithelial cells and to mucins. ${ }^{22,23}$ During the 90s, AFM force spectroscopy has been developed to study, at the piconewton-scale, the interaction forces between individual molecules (ligandreceptor pairs, antibody-antigen, and complementary DNA strands). ${ }^{24}$ More recently, single-cell force spectroscopy has been developed to measure intercellular and interbacterial interactions. ${ }^{25}$ In example, the adhesion of L. lactis cells to pig gastric mucins has been investigated using this strategy and made it possible to decipher between the nonspecific and specific forces at play. ${ }^{26}$ Regarding TIL448 and using AFM force spectroscopy, it was shown that both pili and a mucusbinding protein (Mub proteins) exposed at the bacterial surface contribute to adhesion of L. lactis TIL448 strains to mucins. Mub proteins are bacterial surface adhesins with typical signal peptide and C-terminal LPxTG, which contain multiple Mub domains (around 200 residues) and/or MucBP domains (around 50 residues). ${ }^{13,27,28}$ The comparative study of TIL448 and mutant derivatives expressing pili and Mub proteins or only pili or only Mub proteins enabled to elucidate the L. lactis muco-adhesive phenotype. ${ }^{23}$ On AFM forcedistance curves, showing the force recorded by the cantilever while it is approached and retratced from the surface, the authors observed rupture events both at short (100 to $200 \mathrm{~nm}$ ) and long distances (up to $600-800 \mathrm{~nm}$ ) that they attributed, respectively, to Mub proteins and pili unfolding. ${ }^{29}$ Moreover, the role of pili and Mub proteins in adhesion was investigated under shear stress conditions on the mucin layer. ${ }^{23}$ The results of these experiments showed a more important contribution of the Mub protein compared to pili for the adhesion to the mucin layer.

In the process of biofilm formation, the interactions between cells are of first importance. In this intercellular adhesion, several kinds of molecules among which pili may play a crucial role ${ }^{30}$ in the cohesion of cells in biofilm formation.

In the work presented here, the objective was to analyze homotypic interactions between pili at the single-molecule scale. To reach this goal we used an advanced AFM technique called single-cell force spectroscopy (SCFS) to probe the interactions between pili present on the surfaces of two individual bacteria, thereby allowing to characterize the nanomechanical properties of the pili-pili bond for L. lactis cells expressing more or less pili. The specificity of homotypic interactions was verified by monitoring the pili-pili interactions in the presence of anti-PilB antibodies. The rupture peaks observed on the obtained force curves were then described by the worm-like chain (WLC) model. The results unravelled the role of $L$. lactis pili in homotypic interactions of laboratory strain IL1403 mutants. Experiments conducted on the vegetal isolate TIL448 expressing both pili and Mub proteins further demonstrate the capacity of pili to interact with other surface proteins including Mub proteins. These findings are valuable to understand the influence of pili on adhesion, structuring, and cohesion of the cells during biofilm formation.

\section{MATERIALS AND METHODS}

Bacterial Strains and Growth Conditions. Bacterial strains derived from L. lactis subsp. lactis used in this study are described in Table 1. Strains were grown in M17 broth (Oxoid) containing 0.5\%

\section{Table 1. L. lactis Strains Used in this Study}

\begin{tabular}{|c|c|c|}
\hline strains & genotype or phenotype & source/reference \\
\hline VE17061 & $\mathrm{Pil}^{-}$, control (pili minus) & 16 \\
\hline VE17173 & $\mathrm{Pil}^{+}$, over expression of the pil operon & 16 \\
\hline VE17176 & $\begin{array}{l}\mathrm{Pil}^{++} \text {, over expression of both the pil operon } \\
\text { and the } \operatorname{srtA} \text { gene }\end{array}$ & 16 \\
\hline TIL448 & $\mathrm{Pil}^{+} / \mathrm{Mub}^{+}$, vegetal strain isolated from peas & 22 \\
\hline TIL1230 & $\begin{array}{l}\mathrm{Pil}^{-} / \mathrm{Mub}^{-} \text {, TIL448 derivative obtained by } \\
\text { plasmid curing }\end{array}$ & 22 \\
\hline TIL1289 & $\begin{array}{l}\mathrm{Pil}^{-} / \mathrm{Mub}^{+} \text {, TIL448 derivative obtained by } \\
\text { disruption of the } y g h E 2 \text { gene encoding the } \\
\text { backbone pilin, Ery }\end{array}$ & 22 \\
\hline TIL1290 & $\begin{array}{l}\mathrm{Pil}^{+} \mathrm{Mub}^{-} \text {, TIL448 derivative obtained by } \\
\text { disruption of the mub gene encoding a } \\
\text { mucus-binding protein, Ery }{ }^{\mathrm{R}}\end{array}$ & 22 \\
\hline
\end{tabular}

(w/v) D-glucose (M17 Glc). When required, antibiotics were added to the medium to a final concentration of $5 \mu \mathrm{g} / \mathrm{mL}$ for erythromycin (Ery) and tetracycline (Tet). The strains were incubated overnight at $30{ }^{\circ} \mathrm{C}$ under static conditions.

Bacterial Sample Preparation for AFM Measurements. Overnight cultures were obtained by inoculating $500 \mu \mathrm{L}$ of a cell suspension from frozen stock in $10 \mathrm{~mL}$ of medium. Cultures were harvested by centrifugation ( $1000 \mathrm{~g}, 10 \mathrm{~min}$, at room temperature). The cell pellet was resuspended in phosphate-buffer saline (PBS 1X) solution at $\mathrm{pH} 7.4$ and then diluted up to an optical density of 0.02 at $600 \mathrm{~nm}$ to obtain isolated cells. These cells were then immobilized on dopamine-coated glass coverslips. Briefly, glass coverslips were 

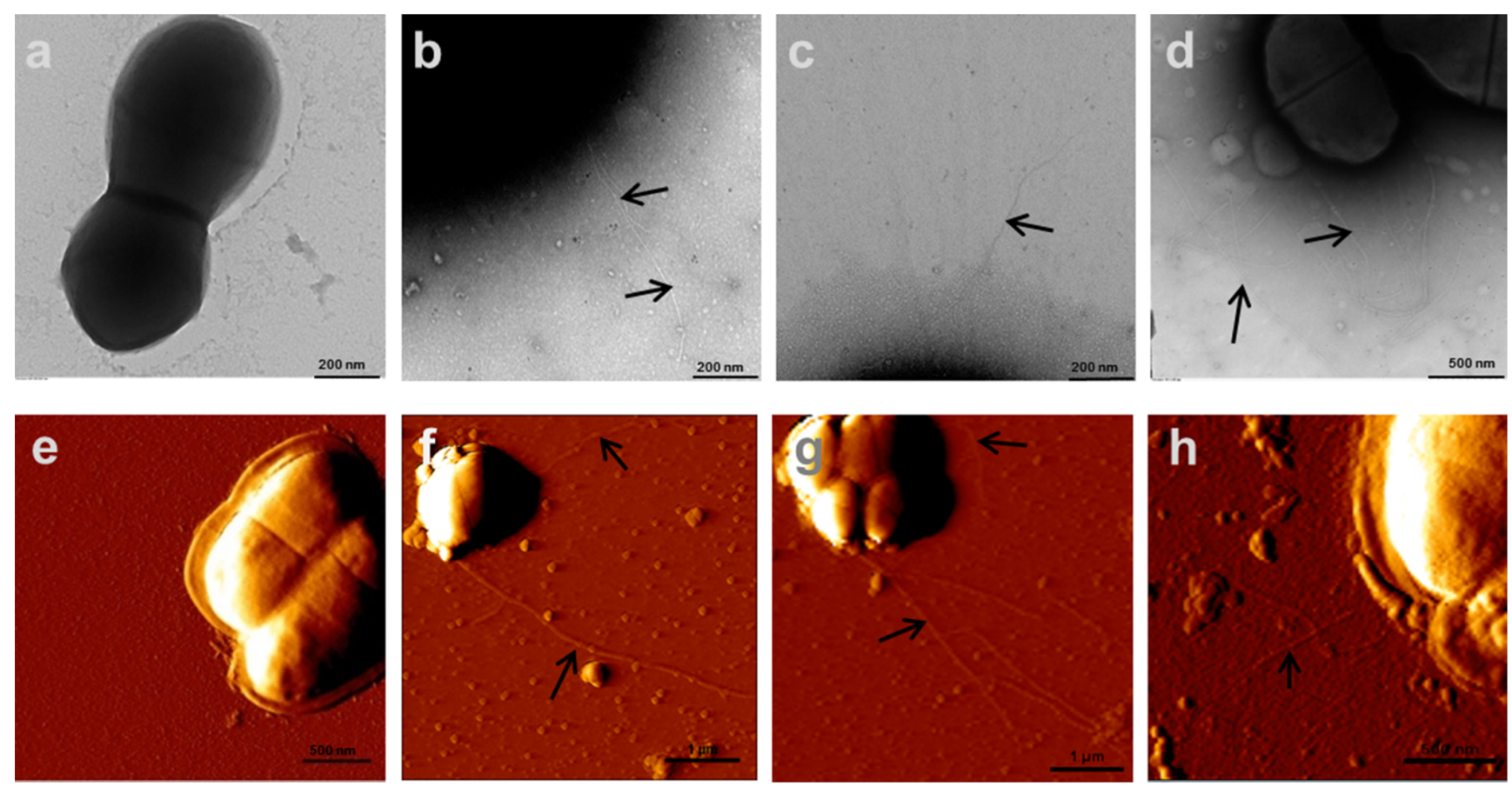

Figure 1. TEM and AFM images of L. lactis pili. TEM images obtained after negative staining of (a) control Pil ${ }^{-}$VE17061, (b) Pil ${ }^{+}$VE17173, (c) $\mathrm{Pil}^{l^{++}}$VE17176, and (d) $\mathrm{Pil}^{+} / \mathrm{Mub}^{+}$TIL448 strains. AFM contact imaging in air of (e) Pil ${ }^{-}$VE17061, (f) Pil ${ }^{+}$VE17173, (g) Pil ${ }^{++}$VE17176, and (h) $\mathrm{Pil}^{+} \mathrm{Mub}^{+}$TIL448 strains. The pili are indicated on the images by the black arrows.

cleaned for 5 min using oxygen plasma and immersed for $48 \mathrm{~h}$ in a PBS 1X solution containing $4 \mathrm{mg} / \mathrm{mL}$ of dopamine hydrochloride (99\%, Sigma). They were then rinsed in Milli-Q-grade water and ethanol and dried under nitrogen. A total of $50 \mu \mathrm{L}$ of the diluted bacterial suspension was then applied to the dopamine-coated glass coverslip, allowed to stand for $30 \mathrm{~min}$ at room temperature, and directly used for AFM single-cell force spectroscopy (SCFS) expriments.

AFM Single-Cell Force Spectroscopy Experiments. Cell probes were prepared using the protocol described in Beaussart et al. Briefly, colloidal probes were obtained by attaching a single silica microsphere ( $5 \mu \mathrm{m}$ diameter, Bangs Laboratories) with a thin layer of UV-curable glue (NOA 63, Norland Edmund Optics) on triangular tipless cantilevers (NP-O10, Bruker, USA) and using a Nanowizard III AFM (Bruker USA). Cantilevers were then immersed for $1 \mathrm{~h}$ in PBS 1X containing $4 \mathrm{mg} / \mathrm{mL}$ of dopamine hydrochloride (SigmaAldrich), rinsed in PBS $1 \mathrm{X}$, and used directly for cell probe preparation. The nominal spring constant of the colloidal probe cantilever was ranging from 0.03 to $0.06 \mathrm{~N} / \mathrm{m}$, as determined by the thermal noise method. ${ }^{31}$ The colloidal probe was then brought into contact with an isolated bacterium and retracted to attach the bacterial cell. Proper attachment of the cell on the colloidal probe was checked using optical microscopy. Cell probes were used to measure cell-cell interaction forces at room temperature, using a maximum applied force of $1 \mathrm{nN}$, a constant approach retraction speed of 2.0 $\mu \mathrm{m} / \mathrm{s}$, and a contact time of $0.5 \mathrm{~s}$. Data were analyzed using the Data Processing software from JPK Instruments (Bruker, USA). Adhesion force and work of adhesion histograms were obtained by calculating the maximum adhesion force and the area under the retract curve, respectively, for each force curve obtained. Unless stated otherwise, for each condition, experiments were repeated for three bacteria coming from independent cultures.

AFM Imaging of $L$. lactis Pili. Bacteria were grown overnight at $30{ }^{\circ} \mathrm{C}$ under static conditions. The following day, $50 \mu \mathrm{L}$ of the cell suspension was diluted in $5 \mathrm{~mL}$ of PBS $1 \mathrm{X}$. A drop of $50 \mu \mathrm{L}$ of the diluted cell suspension was then immobilized on freshly cleaved mica surfaces and incubated at $30{ }^{\circ} \mathrm{C}$ for $3 \mathrm{~h}$. The mica surfaces were then rinsed three times in Milli- $\mathrm{Q}$ water, and the samples were dried in an incubator at $30{ }^{\circ} \mathrm{C}$ for $2 \mathrm{~h}$. Surface topography images of dried bacteria were recorded using AFM in contact mode in air at room temperature, using MLCT cantilevers (Bruker, USA, nominal spring constant of $\sim 0.01 \mathrm{~N} / \mathrm{m}$, as determined using the thermal noise method) with a scanning rate of 1 line/s and a resolution of $512 \times$ 512 lines.

Transmission Electron Microscopy of L. lactis Pili. To check for the presence of pili on the surface of L. lactis strains used in this study, transmission electron microscopy (TEM) and a negative staining procedure were used. Bacterial suspensions from overnight cultures were harvested by centrifugation $(1000 \mathrm{~g}, 10 \mathrm{~min}$ at room temperature) and washed in PBS 1X. Bacterial cells were then fixed using paraformaldehyde (PFA) $3 \%$ during $30 \mathrm{~min}$ at room temperature. Formvar carbon-coated copper grids were rinsed in a drop of fixed bacteria and allowed to stand for $3 \mathrm{~min}$ for the bacterial cells to adsorb over the material. Staining was performed in uranyl acetate $(0.2 \%)$ during $20 \mathrm{~s}$ after washing the grids in Milli- $Q$ water. The grids were dried using a Whatman grad cellulose filter paper. Samples were observed at $75 \mathrm{kV}$ with an H-600 TEM (Hitachi, Japan) equipped with a $1024 \times 1024$ pixel format orca CCD camera. Result images were treated using imageJ software.

\section{RESULTS}

Visualization of Pili in Different L. lactis Strains. As a first step, we checked for the absence/presence of pili at the surface of different $L$. lactis strains (Table 1 ) in our growth conditions, using both transmission electron microscopy (TEM) (representative images: Figure $1 \mathrm{a}-\mathrm{d}$ ) and AFM contact imaging in air (representative images: Figure $1 \mathrm{e}-\mathrm{h}$ ). As expected, both TEM micrographs and AFM images showed pili exhibiting filamentous structures at the surface of cells from strains VE17173 (Figure 1b,f), VE17176 (Figure 1c,g), and TIL448 (Figure 1d,), referred to as $\mathrm{Pil}^{+}, \mathrm{Pil}^{++}$, and $\mathrm{Pil}^{+} \mathrm{Mub}^{+}$, respectively. As expected, no pili were observed at the surface of cells from the Pil ${ }^{-}$VE17061 control strain (Figure 1a,e). Higher numbers of pili were detected in the $\mathrm{Pil}^{++}$VE17176 strain than in the $\mathrm{Pil}^{+}$VE17173 strain, consistent with previous 

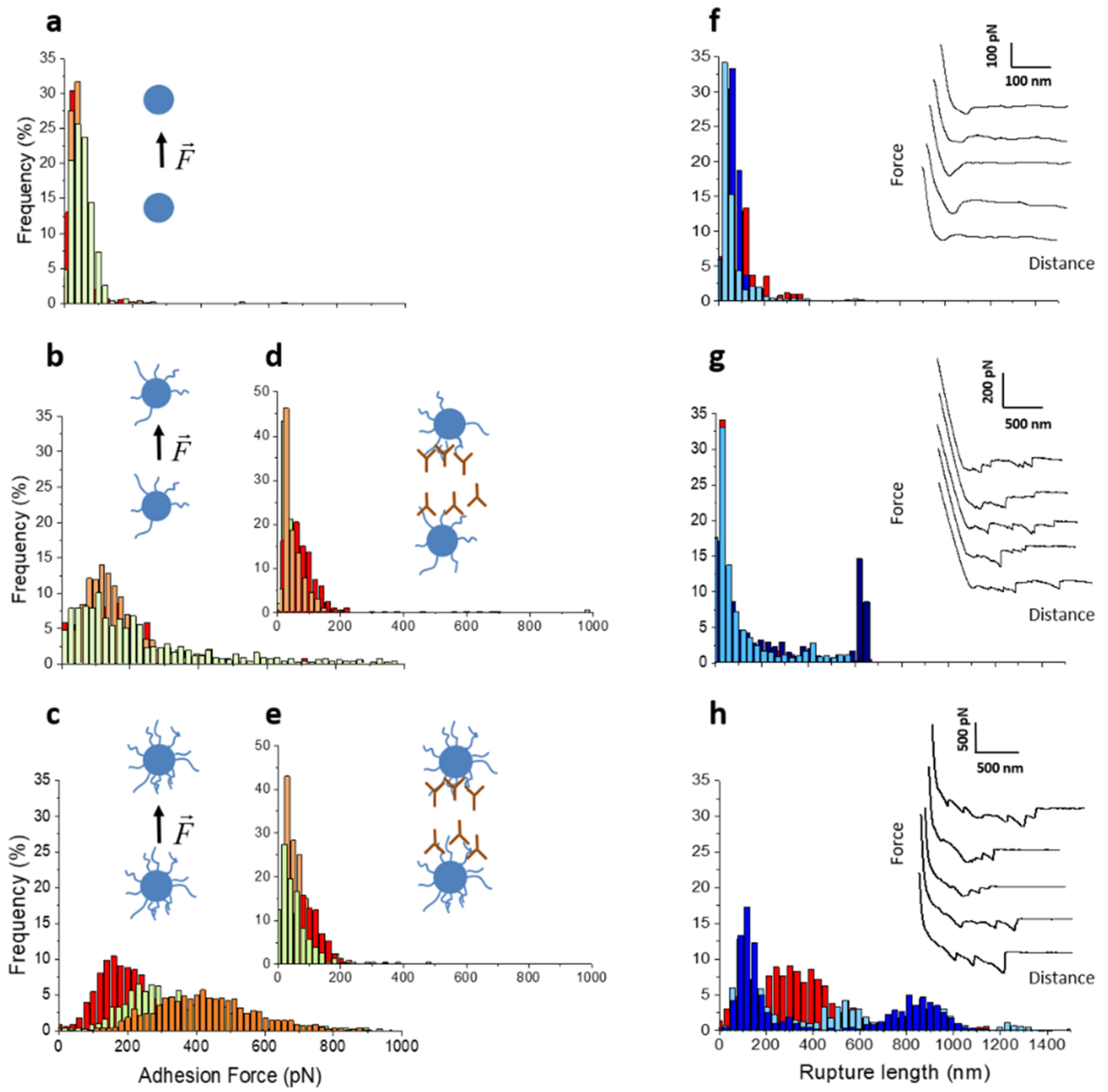

Figure 2. L. lactis pili mediate homotypic interactions between cells. Pili-pili interactions are measured between cell pairs of individual bacteria using single-cell force spectroscopy. Histograms representing the $(\mathrm{a}-\mathrm{e})$ adhesion force, $(\mathrm{f}-\mathrm{h})$ rupture lengths, and typical retraction force curves, obtained by recording force curves between cells of $(a, f)$ the Pil ${ }^{-}$control VE17061, (b, g) the Pil ${ }^{+}$VE17173, and (c, h) the Pil ${ }^{++}$VE17176 strains were reported. For each strain, three independent experiments were conducted (one experiment means three pairs (corresponding to the three colors) of independent cells). The results presented here relate to one experiment and were representative of the three experiments (the two others are presented in Figure S3: homotypic interactions between the $\mathrm{Pil}^{-}$VE17061 cells, Figure S4: homotypic interactions between the Pil ${ }^{+}$VE17173 cells, and Figure S5: homotypic interactions between the Pil ${ }^{++}$VE17176 cells). The total number of analyzed force curves per strain was above 3000 and above 1000 for each histogram. Force measurements performed in the presence of anti-YhgE antibodies in (d) the Pil ${ }^{+}$VE17173 and (e) the $\mathrm{Pil}^{++}$VE17176 strains were reported. $n>1000$ for three pairs cells, representative of three experiments.

western blot analyses in which the former produced greater amounts of oligomerized pilins than the latter. ${ }^{16}$ In Figure 1, the pili are indicated by the black arrows. In the Pil ${ }^{+}$VE17173 strain, the lengths measured were ranging from 200 to 4400 $\mathrm{nm}$ and in average $1178 \pm 1074 \mathrm{~nm}$. The Pil ${ }^{++} \mathrm{VE} 17176$ and the $\mathrm{Pil}^{+} \mathrm{Mub}^{+}$TIL448 strains showed pili lengths between 250 to $4100 \mathrm{~nm}$ and 600 to $5500 \mathrm{~nm}$, respectively. The average lengths were $1424 \pm 1012 \mathrm{~nm}$ for the $\mathrm{Pil}^{++} \mathrm{VE} 17176$ strain and $2930 \pm 1884 \mathrm{~nm}$ for the $\mathrm{Pil}^{+} \mathrm{Mub}^{+}$TIL448 strain. As shown in Figure $1 \mathrm{c}, \mathrm{d}, \mathrm{g}$, pili were tangled and extremely thin with width ranging from 5.22 to $9.32 \mathrm{~nm}$ and the average was $6.7 \pm 1.3$ nm.

\section{Cell-Cell Interactions Are Dominantly Mediated by}

Pili. Then, in the second step, our goal was to characterize, at the molecular level, the homotypic interactions between pili from different $L$. lactis strains used in this study (Table 1). For this purpose, we used single-cell force spectroscopy
(SCFS), ${ }^{32,32,33}$ as described in the Materials and Methods section. The adhesion force measurements recorded between pairs of cells from each strain type are presented in Figure 2. It showed the result of typical force curve analyses obtained for three cells pairs (three different colors) coming from one culture (the results from two other cultures are presented in Figures S3: homotypic interactions between the $\mathrm{Pil}^{-}$VE17061 cells, Figure S4: homotypic interactions between the $\mathrm{Pil}^{+}$ VE17173 cells, and Figure S5: homotypic interactions between the $\mathrm{Pil}^{++}$VE17176 cells). For each force curve, the adhesion force (Figure $2 \mathrm{a}-\mathrm{c}$ ), rupture length (Figure $2 \mathrm{e}-\mathrm{g}$ ), and adhesion work values (Figure $3 a-c$ ) were extracted. The quantification of the adhesion frequency $(19.1 \%$ of adhesive curves) showed that the $\mathrm{Pil}^{-}$VE17061 control strain cells that do not display pili adhered weakly to each other with adhesion forces in the range of $47 \pm 30 \mathrm{pN}$ (mean $\pm \mathrm{SD}$; total number of force curves $=1225$ from three different cell pairs) and an 
a

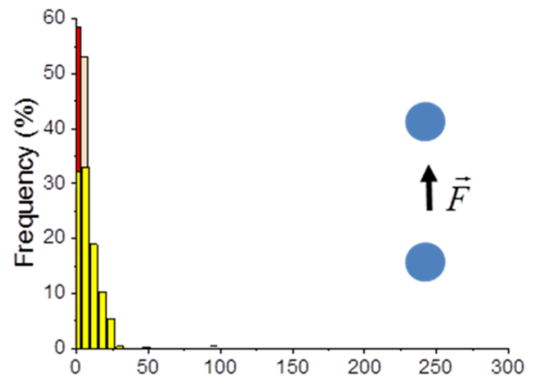

b

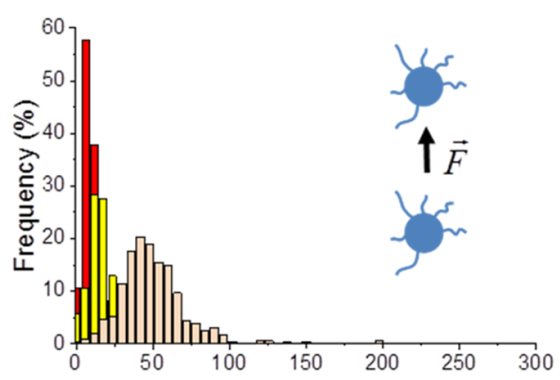

C

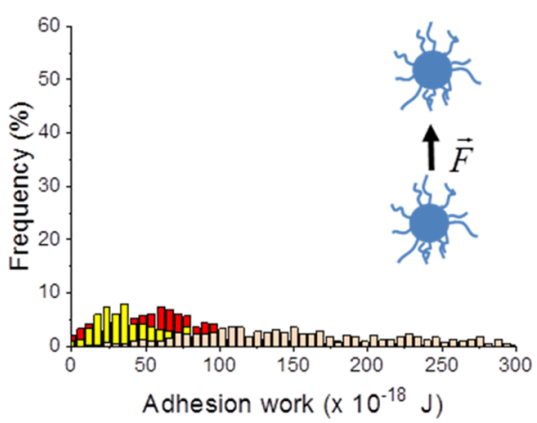

d

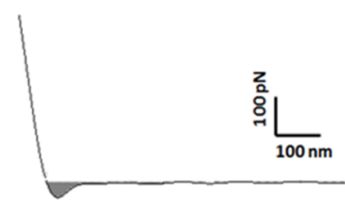

e

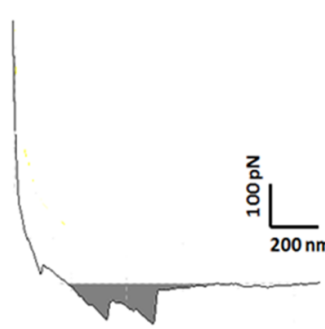

f

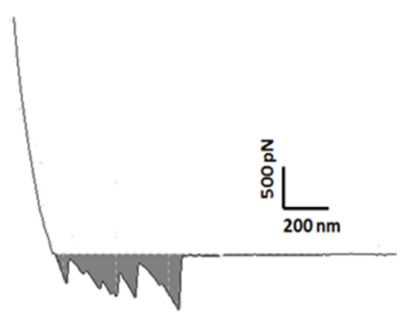

Figure 3. Role of pili-pili homotypic interactions in L. lactis-L. lactis adhesion work. Frequency histograms and typical force distance curves showing the adhesion work observed for (a) the $\mathrm{Pil}^{-}$VE17061 control strain, (b) the Pil ${ }^{+}$VE17173, and (c) the Pil ${ }^{++}$VE17176 strains. The adhesion work is expressed in joule $\left(\times 10^{-18} \mathrm{~J}\right)$ and is determined by measuring the area under the force-distance curves as exemplified on panels $(d-f)$. For each strain, three independent experiments were conducted (one experiment means thee pairs of independent cells).

average rupture distance of $52 \pm 40 \mathrm{~nm}$. In piliated strains, higher adhesion frequencies were found, i.e., 78.0\% in $\mathrm{Pil}^{+}$ VE17173 and $90.1 \%$ in $\mathrm{Pil}^{++}$VE17176 strains. The adhesion forces ranged from $150 \pm 60$ to $198 \pm 99 \mathrm{pN}$ (mean $\pm \mathrm{SD}$; total number of force curves $=1817$ from three different cell pairs) for the Pil ${ }^{+}$VE17173 strain and from $182 \pm 75$ to $452 \pm$ $150 \mathrm{pN}$ (mean $\pm \mathrm{SD}$; total number of force curves $=2914$ from three different cell pairs) for the $\mathrm{Pil}^{++}$strain. As for the rupture lengths, they reached $634 \pm 103 \mathrm{~nm}$ for the $\mathrm{Pil}^{+}$ VE17173 strain and $874 \pm 147 \mathrm{~nm}$ for the $\mathrm{Pil}^{{ }^{++}}$VE17176 strain. Force curves recorded for piliated strains showed multiple adhesive events that were absent in the $\mathrm{Pil}^{-}$VE17061 control strain suggesting that they were related to pili-pili interaction (see below). To further investigate this point, we performed several control tests in which we probed the interactions between piliated and pili-devoided control strain cells (Supporting Information, Figure S1: heterotypic interaction between $\mathrm{Pil}^{+}$VE17173 and $\mathrm{Pil}^{-}$VE17061). This showed a weak adhesion force $(73 \pm 47 \mathrm{pN})$ similar to the interaction between cell pairs of the control strain. Moreover, other control tests were performed to study the specificity of pili-pili interactions. To go one step further in the probing of piluspilus interactions, we reasoned that because the pilus backbone is constituted of oligomers of the YhgE pilin and because these oligomers have been shown to be the essential determinant for the adhesion of piliated cells under shear flow conditions, ${ }^{20}$ anti-YhgE antibodies ${ }^{16}$ should be able to block pilus-pilus interactions. As reported in Figure 2d,e, major reductions in the adhesion force $\left(24.1 \pm 11.6\right.$ to $64.8 \pm 43.8 \mathrm{pN}$ for the $\mathrm{Pil}^{+}$ VE17173 strain and $31.4 \pm 22.5$ to $75.2 \pm 55.3 \mathrm{pN}$ for the $\mathrm{Pil}^{++}$VE17176 strain) were monitored thus proving that the interactions probed were indeed due to interactions between YhgE pilins.

To further probe the homotypic interactions between pili, we determined the work of adhesion involved. The adhesion work was calculated as the area between the retract force curve 
a

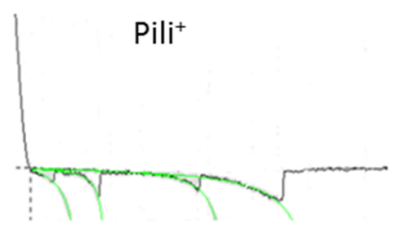

b

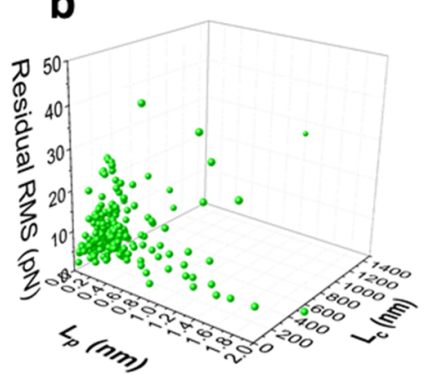

C

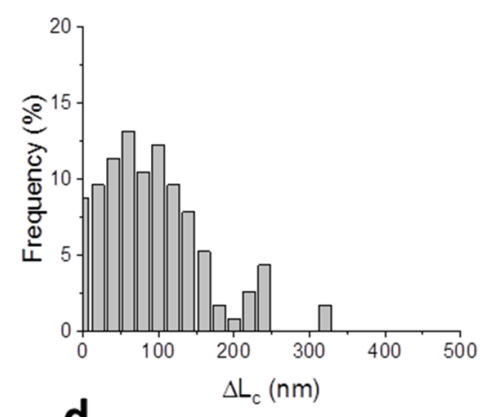

d

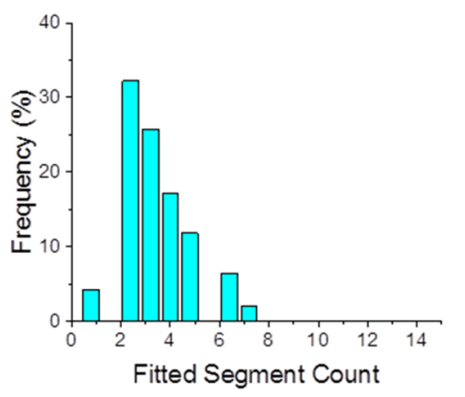

e
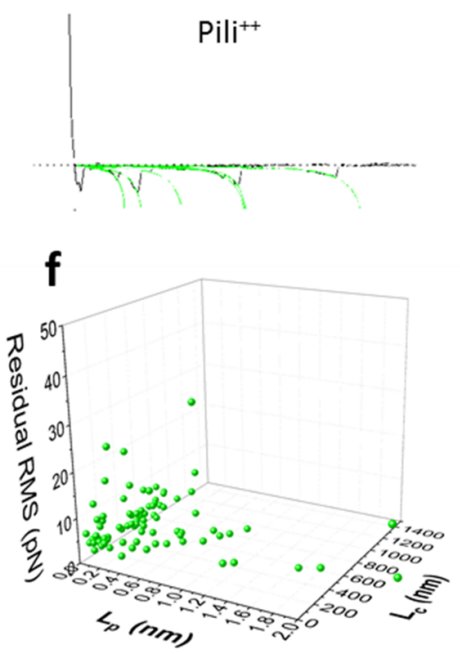

g

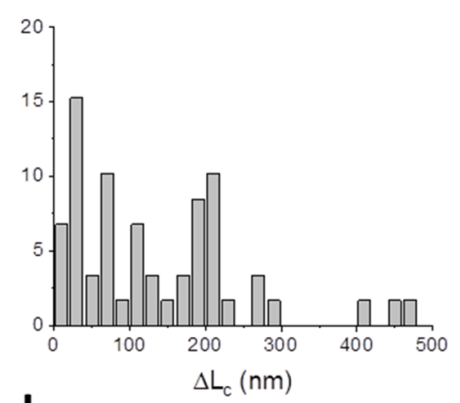

h

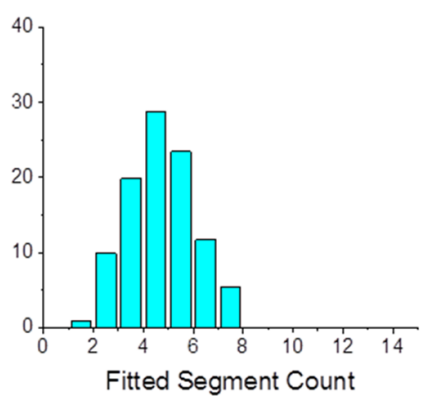

Figure 4. Pili-pili homotypic interaction: analysis of the force signature. Unfolding curves were fitted using the worm-like chain model (WLC). (a, e) Typical unfolding curves (black lines) respectively from the Pil ${ }^{+}$VE17173 and Pil ${ }^{++}$VE17176 strains and typical fits (green lines). The contour length $\left(L_{\mathrm{c}}\right)$, persistence length $\left(L_{\mathrm{p}}\right)$, and RMS residual relations are presented in $(\mathrm{b})$ and $(\mathrm{f})$. The distance between $(\mathrm{c}, \mathrm{g})$ two consecutive rupture $\left(\Delta L_{c}\right)$ and $(\mathrm{d}, \mathrm{h})$ the number of fitted segment per curve respectively from the Pil ${ }^{+}$VE17173 and the Pil ${ }^{++}$VE17176 strains were analyzed.

and the baseline of this force curve, as illustrated in Figure $3 \mathrm{~d}-$ f. The results presented in Figure $3 a-c$ showed that interactions between cells of piliated strains engage an important energy, ranging from $15 \times 10^{-18} \pm 7$ to $47 \times$ $10^{-18} \pm 15$ joule $(\mathrm{J})$ for the $\mathrm{Pil}^{+}$cells and up to $108 \times 10^{-18} \pm$ $27 \mathrm{~J}$ for the $\mathrm{Pil}^{++}$ones, compared to the $\mathrm{Pil}^{-}$control strain that engages only $7 \times 10^{-18} \pm 0.5 \mathrm{~J}$. These values indicate stronger interactions between piliated cells and suggest that pili play a crucial role in adhesion of cell to cells.

Force Curve Signatures Description Using the Wormlike Chain (WLC) Model. To understand, at the physical level, the different force peaks observed during the extension of a pilus-pilus complex (or pili-pili complex) (Figure $2 \mathrm{e}-\mathrm{g}$ ), we used the WLC model. The WLC model is commonly used to describe the force-extension response of linear polymers that undergo thermal fluctuations. This model is usually used to describe macromolecule extension and is expressed in the following equation: ${ }^{34-36}$

$$
F(x)=-k_{\mathrm{b}} T / L_{\mathrm{p}}\left[1 / 4\left(1-x / L_{\mathrm{c}}\right)-2+x / L_{\mathrm{c}}-1 / 4\right]
$$

where $F$ is the force $(\mathrm{N}), k_{\mathrm{b}}$ is the Boltzmann constant $(\mathrm{J} /$ Kelvin), $T$ is the temperature (Kelvin), $L_{\mathrm{p}}$ is the persistence length $(\mathrm{m}), L_{\mathrm{c}}$ is the total contour length $(\mathrm{m})$ of the macromolecule, and $x$ is the molecule extension $(\mathrm{m})$. Other conformational parameters were determined such as the distance between two consecutive ruptures $\left(\Delta L_{\mathrm{c}}\right)$ (Figure $4 c, g$ ), the number of fitted segment per force curve (Figure $4 \mathrm{~d}, \mathrm{~h})$, and the fitting quality, evaluated by the residual Root Mean Square (residual RMS) values. The fitting of typical unfolding force curves (Figure $4 \mathrm{a}, \mathrm{e}$ ) respectively from the $\mathrm{Pil}^{+}$ 
a

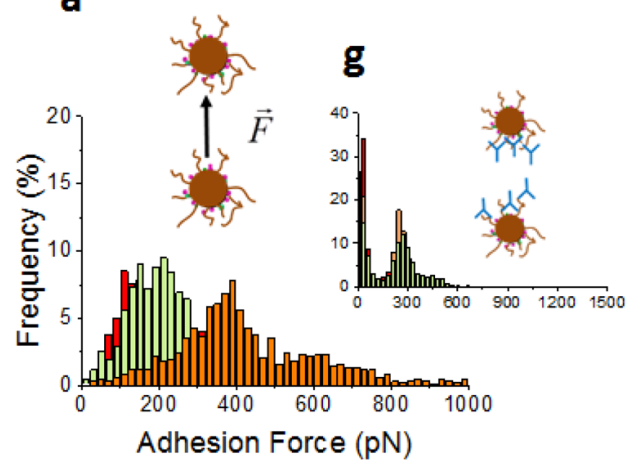

d

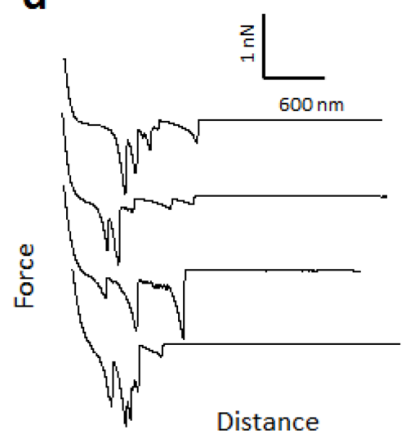

b

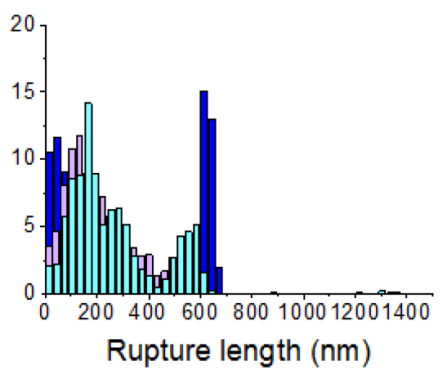

e

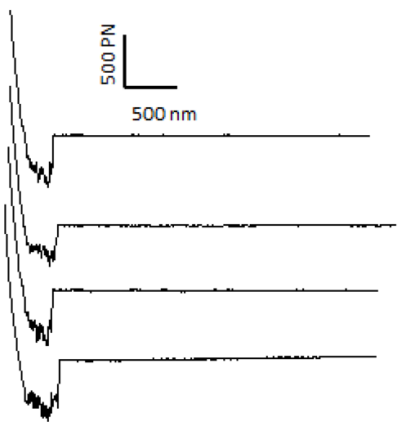

C

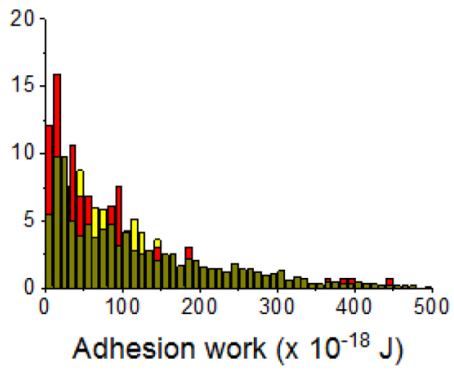

f

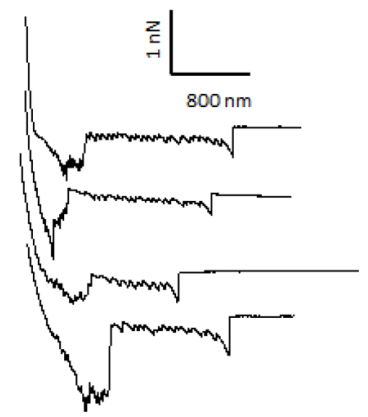

Figure 5. Cell-cell interactions of the plant isolate L. lactis TIL448 involve pili-pili homotypic interactions and more complex interactions. (a-c) Histograms of the adhesion force, rupture length, and adhesion work of the self-interaction of TIL448, respectively. (d-f) Representative of the three types of force curves recorded for this self-interaction. Force curves of three pairs of cells, representing three independent experiments, have been analyzed $(n>1000)$. Force measurements were also performed in the presence of anti-YhgE, and the histogram frequency of the adhesion force is represented in $(\mathrm{g})(n>1000)$.

$\operatorname{VE} 17173(n=92)$ and the Pil ${ }^{++} \operatorname{VE} 17176$ strains $(n=50)$ were analyzed. The frequency distribution of $L_{\mathcal{c}}, L_{\mathrm{p}}$, and residual RMS values are presented on 3D graphs in Figure 4b,f. The $L_{\mathrm{p}}$ values obtained for both the $\mathrm{Pil}^{+}$VE17173 and the $\mathrm{Pil}^{++}$ VE17176 strains were in between 0.05 and $0.6 \mathrm{~nm}$ and reach 1 $\mathrm{nm}$ at maximum. The $L_{\mathrm{c}}$ values were variable and ranged from 50 to $800 \mathrm{~nm}$ for the $\mathrm{Pil}^{+} \mathrm{VE} 17173$ strain and from 100 to $1000 \mathrm{~nm}$ for the $\mathrm{Pil}^{++}$VE17176 strain. The fit parameters were those providing the lowest RMS values, or in other words, those providing the best quality of the fit. We found the smallest residual RMS when $L_{\mathrm{p}}$ and $L_{\mathrm{c}}$ were freely adjustable parameters. Indeed, the residual RMS on $L_{\mathrm{p}}$ and $L_{\mathrm{c}}$ for the $\mathrm{Pil}^{+}$ VE17173 strain or the $\mathrm{Pil}^{++}$VE17176 strain were found to be 3 and $6.7 \mathrm{pN}$, respectively, in the case of freely adjustable parameters, and increased up to $379 \mathrm{pN}$ in the case of an $L_{\mathrm{p}}$ value fixed to $0.4 \mathrm{~nm}$ (Supporting Information, Figure S10: analysis of various force signatures obtained in pili-pili interactions between the $\mathrm{Pil}^{++} \mathrm{VE} 17176$ cells and Figure S11: analysis of various force signatures obtained in pili-pili interactions in $\mathrm{Pil}^{+} \mathrm{Mub}^{+}$TIL448 strains).

In these conditions, we found $\Delta L_{\mathrm{c}}$ values between 25 and $200 \mathrm{~nm}$ and three to four unfolding events (corresponding to the number of interacting pili) for the $\mathrm{Pil}^{+} \mathrm{VE} 17173$ strain (Figure $4 \mathrm{c}, \mathrm{d}$ ). As for the Pil ${ }^{++}$VE17176 strain, the $\Delta L_{\mathrm{c}}$ values ranged from 25 to $300 \mathrm{~nm}$ (Figure $4 \mathrm{~g}$ ) and the numbers of fitted segment were of 5 to 6 (Figure $4 \mathrm{~h}$ ). These values of $L_{\mathrm{p}}$ (which are small, i.e., in the range of 0.05 to $0.6 \mathrm{~nm}$ ), $L_{\mathrm{c}}$ (up to $800 \mathrm{~nm}$ ), and $\Delta L_{\mathrm{c}}$ (up to $300 \mathrm{~nm}$ ) measured in both $\mathrm{Pil}^{+}$
VE17173 and $\mathrm{Pil}^{++}$VE17176 strains indicate that pili are long, rigid, but flexible biopolymers. This results in long range interactions between cells that are hydrodynamically stable. ${ }^{20}$ The interactions exhibited, randomly, different lengths, as it can also be seen in the microscopic images (Figure 1).

Cell-Cell Interactions in a Plant Isolate L. lactis TIL448. In order to strengthen the above conclusions, we decided to challenge our results obtained with engineered laboratory strains by comparing them with those obtained in an environmental strain that naturally produces pili (TIL448). To reach this goal, we studied the interactions between two TIL448 cells. L. lactis TIL448 not only produces pili but also produces Mub proteins known for their adhesive properties to mucin layers. Using SCFS experiments, the adhesion between individual cell pairs was measured with three independent cell pairs (Figure 5) showing large adhesion forces ranging from $197 \pm 83$ to $372 \pm 82 \mathrm{pN}(n=3795$ force curves in Figure 5a) on almost all the recorded force curves (the adhesion frequency is $97.9 \%$ ). The rupture length was as high as 627 $\pm 21 \mathrm{~nm}$ (Figure 5b) and could reach $1.2 \mu \mathrm{m}$ (showed in Figure S6: homotypic interactions between the $\mathrm{Pil}^{+} \mathrm{Mub}^{+}$ TIL448 cells). These values, in addition to the adhesion work values over $50 \times 10^{-18} \pm 16 \mathrm{~J}$ (Figure $5 \mathrm{c}$ ), were of the same order of magnitude to that of the adhesion frequency, force, rupture distance, and work obtained with the laboratory piliated strains $\left(\mathrm{Pil}^{+}\right.$and $\left.\mathrm{Pil}^{++}\right)$. To challenge the importance of pili in the interactions measured, we once again performed the blocking test by adding anti-YhgE antibody in the solution; this 

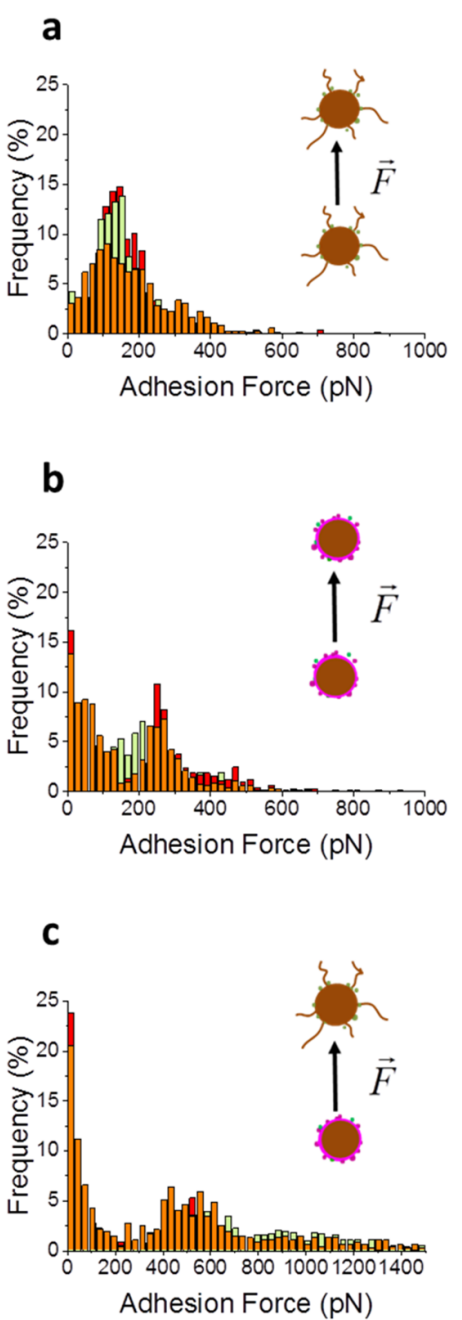
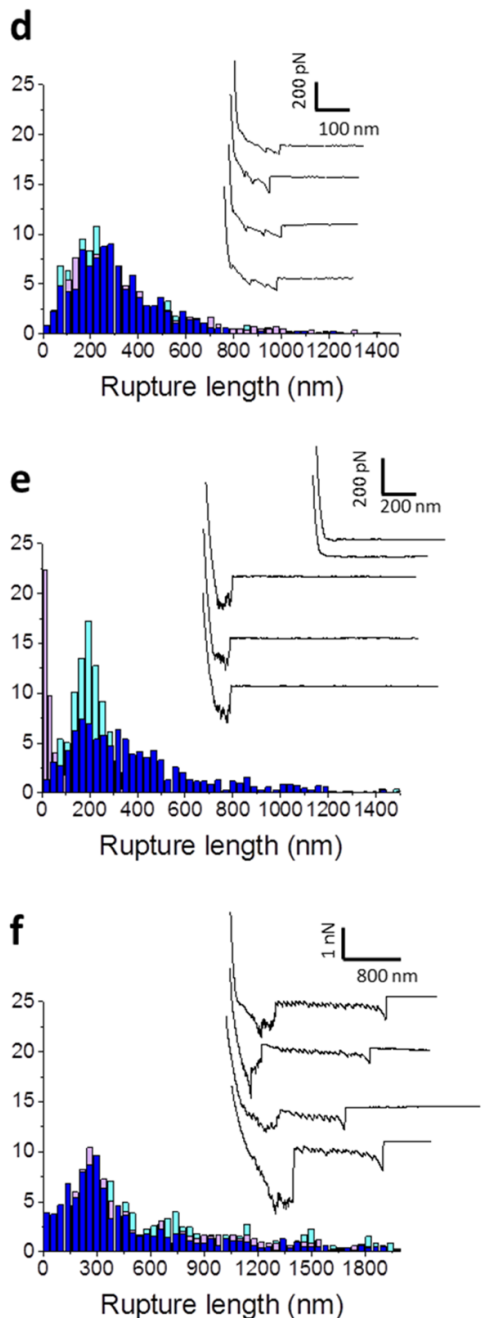
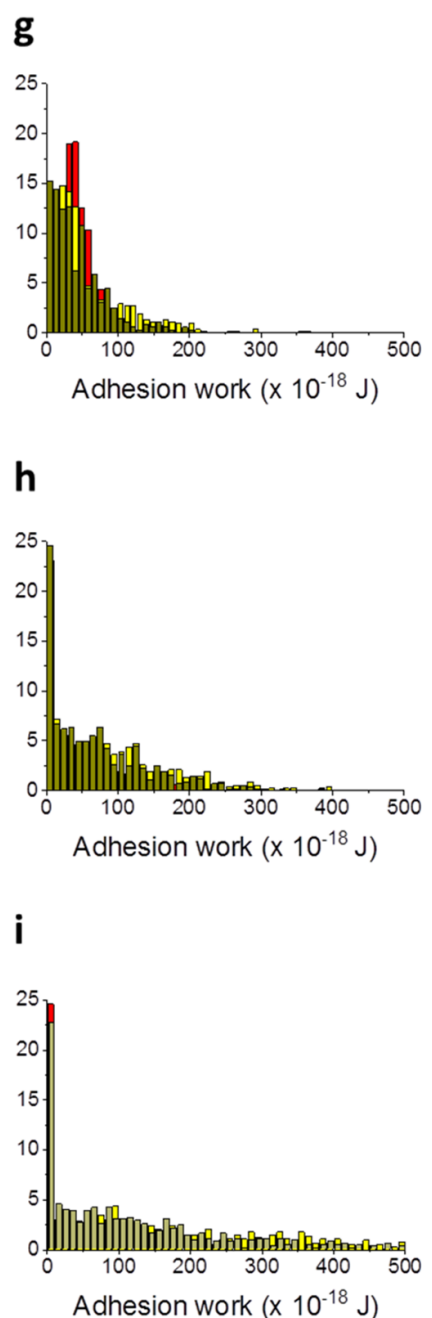

Figure 6. Analysis of cell-cell interactions on mutants from TIL448. $(a-c)$ Adhesion frequency, $(d-f)$ rupture distance and typical force distance curves, and (g, h, i) adhesion work were measured between cell pairs of (a, d, f) Pil ${ }^{+}$Mub $^{-}$TIL 1290, (b, e, h) cell pairs of Pil ${ }^{-}$Mub $^{+}$TIL1289, and heteropairs of TIL1290 with TIL1289. Each condition has been tested three times with three pairs using cells coming from indpendent cultures. The results presented here are coming from three pairs, representative of the three indepedently performed experiments. The other two cultures are in Figure S7: homotypic interactions between Pil ${ }^{+} \mathrm{Mub}^{-}$TIL1290 cells, Figure S8: homotypic interactions between Pil ${ }^{-} \mathrm{Mub}^{+} \mathrm{TIL}^{2} 289$ cells, and $^{-}$ Figure S9: heterotypic interactions between $\mathrm{Pil}^{+} \mathrm{Mub}^{-} \mathrm{TIL} 1290$ and Pil ${ }^{-} \mathrm{Mub}^{+} \mathrm{TIL} 1289$ cells.

resulted in a dramatic decrease in the adhesion rate to only $30.3 \%$ (Figure $5 \mathrm{~g}$ ).

By taking a closer look at the force curves obtained, we were able to decipher three different classes of signatures (examples showed in Figure $5 \mathrm{~d}-\mathrm{f}$ ) indicating different types of interaction modes probably resulting from different molecules interacting with each others at the surface of TIL448 cells.

To identify the nature of these different interacting proteins and their correspondence to the typical force curves observed in Figure 5d-f, we used three TIL448 strain derivatives (Table 1): $\mathrm{Pil}^{+} \mathrm{Mub}^{-} \mathrm{TIL} 1290, \mathrm{Pil}^{-} \mathrm{Mub}^{+} \mathrm{TIL} 1289$, and $\mathrm{Pil}^{-} \mathrm{Mub}^{-}$ TIL1230. Using these strains, we analyzed both homotypic interactions for each strain and heterotypic interactions taking place between the $\mathrm{Pil}^{+} \mathrm{Mub}^{-} \mathrm{TIL} 1290$ strain and $\mathrm{Pil}^{-} \mathrm{Mub}^{+}$ TIL1289 strain.

In the $\mathrm{Pil}^{+} \mathrm{Mub}^{-}$TIL1290 strain, cell-cell interactions showed that the adhesion force, rupture length, and adhesion work were $130 \pm 55 \mathrm{pN}, 255 \pm 138 \mathrm{~nm}$, and $39 \times 10^{-18} \pm 11$ $\mathrm{J}$, respectively, for $89.7 \%$ of the force curves (Figure 6a,d,g) $($ mean $\pm S D$; total number of force curves $=1319$ and from three different cell pairs). The other two cultures are in Figure S7: homotypic interactions between $\mathrm{Pil}^{+} \mathrm{Mub}^{-} \mathrm{TIL} 1290$ cells. The force curve shape between $\mathrm{Pil}^{+} \mathrm{Mub}^{-} \mathrm{TIL} 1290$ cells was very similar to those obtained above with the $\mathrm{Pil}^{+}$and $\mathrm{Pil}^{++}$ strains (Figure 2f,g), indicating that the pili-pili interactions had a specific force signature corresponding to Figures $4 a, e, 5 d$, or $6 \mathrm{~d})$. For the $\mathrm{Pil}^{-} \mathrm{Mub}^{+} \mathrm{TIL} 1289$ strain, we observed both a high level of nonadhesive events $(63.4 \%)$ and a high adhesion force (36.6\% of curves) of $255 \pm 23 \mathrm{pN}$ (Figure $6 \mathrm{~b}$ ). The rupture length (Figure 6e) was measured to be $202.0 \pm 0.2 \mathrm{~nm}$ and most of the cells (63.4\% of force curves) showed low energy $\left(9.1 \times 10^{-18} \pm 10.4 \mathrm{~J}\right)$, while a high energy $(38.8 \times$ $10^{-18} \pm 17 \mathrm{~J}$ ) was observed for only $36.6 \%$ of force curves (Figure $6 \mathrm{~h}$ ). The force curve signatures presenting a sawtoothshaped pattern are comparable to those observed in Figure 5e corresponding to Mub protein unfolding. The interaction between the $\mathrm{Pil}^{+} \mathrm{Mub}^{-}$TIL1290 and $\mathrm{Pil}^{-} \mathrm{Mub}^{+}$TIL1289 cells ( $n=2227$ force curves) (Figure $6 \mathrm{c}, \mathrm{f}, \mathrm{i}$ ) showed nonadhesive frequency for $55.9 \%$ of the force curves and only $44.1 \%$ present a high adhesion force $(559 \pm 165 \mathrm{pN})$ and work of adhesion 
Table 2. Summary Table of Results ${ }^{a}$

\begin{tabular}{|c|c|c|c|c|c|c|c|c|c|c|}
\hline strains & $\mathrm{Pil} / \mathrm{Mub}$ & $\begin{array}{c}\text { adhesion } \\
\text { frequency (\%) }\end{array}$ & $\begin{array}{l}\text { adhesion force } \\
(\mathrm{pN})\end{array}$ & $\begin{array}{c}\text { rupture } \\
\text { distance }(\mathrm{nm})\end{array}$ & $\begin{array}{l}\text { adhesion work } \\
\left(\times 10^{-18} \mathrm{~J}\right)\end{array}$ & $L_{\mathrm{c}}(\mathrm{nm})$ & $L_{\mathrm{p}}(\mathrm{nm})$ & $\begin{array}{r}\Delta L_{\mathrm{c}} \\
(\mathrm{nm})\end{array}$ & $\begin{array}{l}\text { number of fitted } \\
\text { segments }\end{array}$ & $\begin{array}{l}\text { RMS } \\
(\mathrm{pN})\end{array}$ \\
\hline VE17061 & $-/-$ & 19.1 & $47 \pm 30$ & $52 \pm 40$ & $7 \pm 0.5$ & nd & nd & nd & nd & nd \\
\hline VE17173 & $+/-$ & 78.0 & $\begin{array}{l}150 \pm 60 \text { to } 198 \\
\pm 99\end{array}$ & $\begin{array}{l}\text { reach } 634 \pm \\
103\end{array}$ & $\underset{15}{15 \pm 7 \text { to } 47 \pm}$ & $\begin{array}{r}50 \text { to } \\
800\end{array}$ & $\begin{array}{l}0.05 \text { to } \\
0.6\end{array}$ & $\begin{array}{r}25 \text { to } \\
200\end{array}$ & 3 to 4 & 6.7 \\
\hline VE17176 & $++/-$ & 90.1 & $\begin{array}{l}182 \pm 75 \text { to } 452 \\
\pm 150\end{array}$ & $874 \pm 147$ & up to $108 \pm 27$ & $\begin{array}{r}100 \text { to } \\
1000\end{array}$ & $\begin{array}{l}0.05 \text { to } \\
0.6\end{array}$ & $\begin{array}{r}25 \text { to } \\
300\end{array}$ & 5 to 6 & 3.0 \\
\hline TIL448 & $+/+$ & 97.9 & $\begin{array}{l}197 \pm 83 \text { to } 372 \\
\pm 82\end{array}$ & $\underset{21}{u_{21} \text { to } 627 \pm}$ & over $50 \pm 16$ & nd & nd & nd & nd & nd \\
\hline TIL1230 & $-/-$ & 16.8 & $29 \pm 16$ & $59 \pm 32$ & $5.3 \pm 1.5$ & nd & nd & nd & nd & nd \\
\hline TIL1289 & $-/+$ & 36.6 & $255 \pm 23$ & $202 \pm 0.2$ & $38.8 \pm 17$ & $\begin{array}{c}200 \text { to } \\
600\end{array}$ & 0.051 & 50 & 8 to 10 & 20.0 \\
\hline TIL1290 & $+/-$ & 89.7 & $130 \pm 55$ & $255 \pm 138$ & $39.1 \pm 11$ & $\begin{array}{r}200 \text { to } \\
1200\end{array}$ & $\begin{array}{c}0.05 \text { to } \\
0.15\end{array}$ & $\begin{array}{r}25 \text { to } \\
250\end{array}$ & 12 to 18 & 6.7 \\
\hline $\begin{array}{l}\text { TIL1290/ } \\
\text { TIL1289 }\end{array}$ & $\begin{array}{l}+/- \\
-/+\end{array}$ & 44.1 & $559 \pm 165$ & $\operatorname{up}_{95}$ to $1500 \pm$ & $131 \pm 125$ & $\begin{array}{r}300 \text { to } \\
1500\end{array}$ & until 0.2 & 50 & 12 to 18 & 10.0 \\
\hline
\end{tabular}

$\left(131 \times 10^{-18} \pm 125 \mathrm{~J}\right)$. The rupture length was up to $1500 \pm$ $95 \mathrm{~nm}$. The analysis of the different force curves shows three different profile types. Among the adhesive curves, some showed typical Mub protein unfoldings while others were similar to those observed in Figure $5 \mathrm{f}$ and included the detachement of Mub protein before the sliding of pili on the Mub protein. The hypothesis is that several Mub proteins on the cell surface act as adhesins along the pili. The force applied on the pili then results in successive detachement of Mub-pili interactions, which we called sliding and was also described as zipper interactions in L. rhamnosus GG. ${ }^{14}$

Finally, and as expected, the $\mathrm{Pil}^{-} \mathrm{Mub}^{-} \mathrm{TIL} 1230$ strain showed a dramatic decrease in the adhesion force, distance rupture, and adhesion work to $29 \pm 16 \mathrm{pN}, 59 \pm 32 \mathrm{~nm}$, and $5.3 \times 10^{-18} \pm 1.5 \mathrm{~J}$, respectively (Supporting Information, Figure S2: homotypic interaction in TIL1230).

To facilitate the comparison between strains, the results concerning the adhesion, force and work, rupture distance, adhesion frequency, etc., are gathered in a recapitulative table (Table 2).

Description of Various Force Signatures in the Plant Isolate L. lactis TIL448. Similar to piliated derivatives from IL1403 strains (Table 1), the different force peaks obtained in TIL448 cell interactions were well described by the WLC model. The typical force curves for pili (Figure 7a) and Mub protein (Figure $7 \mathrm{e}$ ) unfolding and the signatures resulting of the sliding of pili to Mub proteins (Figure $7 \mathrm{i}$ ) were analayzed. For pili signatures, as shown in Figure $7 \mathrm{~b}$, the $L_{\mathrm{p}}$ values were between 0.05 to $0.15 \mathrm{~nm}$, the $L_{\mathrm{c}}$ values were from 200 to 1200 $\mathrm{nm}$, and the $\Delta L_{\mathrm{c}}$ were variable (between 25 to $250 \mathrm{~nm}$ ) (Figure $7 \mathrm{c}$ ). The number of fitted segment varied between 2 and 6 (Figure $7 \mathrm{~d}$ ). These values were similar to those found with the laboratory IL1403 piliated strains. Figure $7 \mathrm{f}$ shows that the $L_{\mathrm{p}}$ and $L_{\mathrm{c}}$ values of Mub protein unfolding (sawtooth signatures) were more homogeneous and about $0.051 \mathrm{~nm}$ and from 200 to $600 \mathrm{~nm}$, respectively. The $\Delta L_{\mathrm{c}}$ value was fixed at $50 \mathrm{~nm}$ (Figure $7 \mathrm{~g}$ ) and the number of fitted segments from 8 to 10 (Figure $7 \mathrm{~h}$ ). The $\Delta L_{\mathrm{c}}$ value was also at $50 \mathrm{~nm}$ (Figure $7 \mathrm{k}$ ) when we analyzed the peak obtained by the pili sliding on Mub proteins (sawtooth signatures and the last corresponds to the pili detachment, Figure 7i). The $L_{\mathrm{p}}$ was up to $0.2 \mathrm{~nm}$, the $L_{c}$ was between 300 to $1500 \mathrm{~nm}$ (Figure 7j), depending on the length of the pili sliding on the Mub proteins. The number of fitted segments was 12 to 18 (Figure 71). All the fits had residual RMS values below $20 \mathrm{pN}$ demonstrating the good fitting quality compared to the values obtained when we fixed $L_{\mathrm{p}}$ to one value (Supporting Information, Figure S12: analysis of various force signatures of Mub proteins obtained in the interactions between the $\mathrm{Pil}^{-} \mathrm{Mub}^{+}$TIL1289 cells, Figure S13: analysis of various force signatures obtained in the interactions between the $\mathrm{Pil}^{+} \mathrm{Mub}^{-}$TIL1290 and the $\mathrm{Pil}^{-} \mathrm{Mub}^{+}$TIL1289 cells).

\section{DISCUSSION}

For several decades, most of the investigations on pili were conducted in pathogens because of their role in colonization, infection, and virulence. ${ }^{1,4,37}$ It was only recently that pili were also evidenced and characterized in food and probiotic bacteria such as L. lactis or Lactobacillus rhamnosus GG. ${ }^{13}$ In this study, we raised the question of the pili function in the group of lactic acid bacteria (LAB).

$\mathrm{LAB}$ were natural inhabitants of agricultural products such as plants and milk and they were used as starters in a number of food fermentation processes. As such, LAB were likely to occur as biofilms on various food (processing) surfaces and host mucosal cells. ${ }^{38,39}$ In this regard, the role of pili in mucin and collagen binding, the two major extracellular components of host epithelial layers, have been extensively investigated in L.s rhamnosus. ${ }^{14}$ Further, single-cell approaches were used to probe interactions of $\mathrm{LAB}$ cells through their surface proteins, in order to understand biofilm formation in positive or detrimental situations.

In laboratory strains, the results showed that piliated strains reached an adhesion force of $\sim 600 \mathrm{pN}$ while it was less than $100 \mathrm{pN}$ for control cells. These results suggested that pili are involved in the interactions between cell pairs. In addition, we observed a difference in adhesion force between cell pairs from the same culture and between $\mathrm{Pil}^{+}$and $\mathrm{Pil}^{++}$bacteria suggesting that (i) the number of pili at the bacterial surface is not constant and (ii) the number of pili can influence the adhesion abilities. To clear this point, we performed several control experiments including the one presented in Figure S1: heterotypic interaction between $\mathrm{Pil}^{+} \mathrm{VE} 17173$ and $\mathrm{Pil}^{-}$ VE17061. This revealed weak adhesion force and work combined with short rupture length, clearly demonstrating that such interactions have no role in cell-cell interactions. To further validate the direct implication of homotypic interactions of pili in cell-cell interactions, we used anti-YhgE 
a

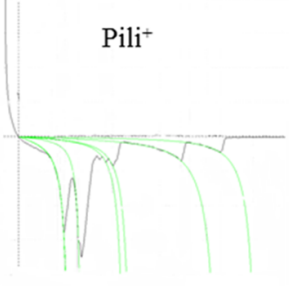

b

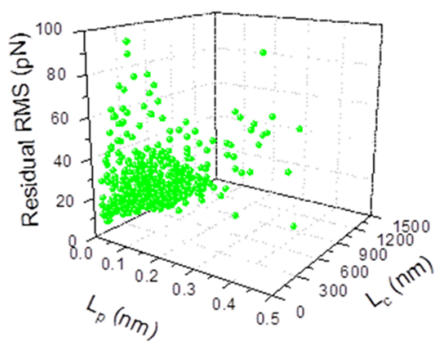

C

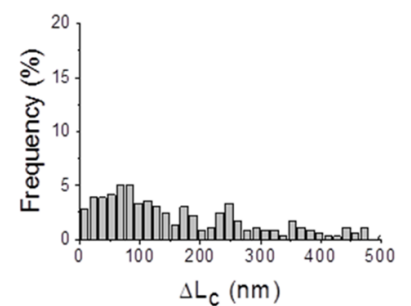

d

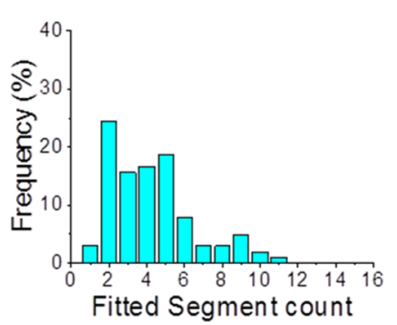

e

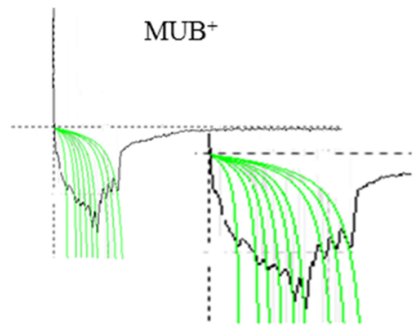

f

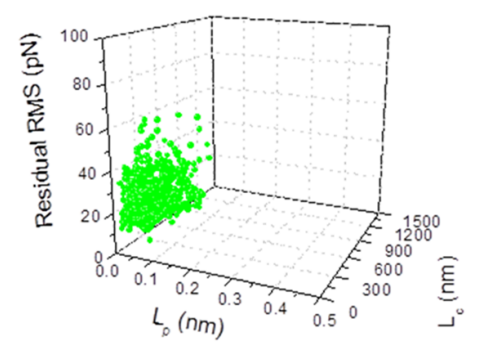

g

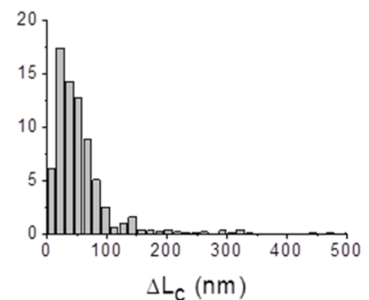

h

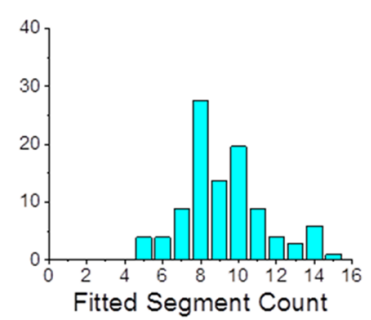

$\mathrm{Pili}^{+} / \mathrm{MUB}^{+}$
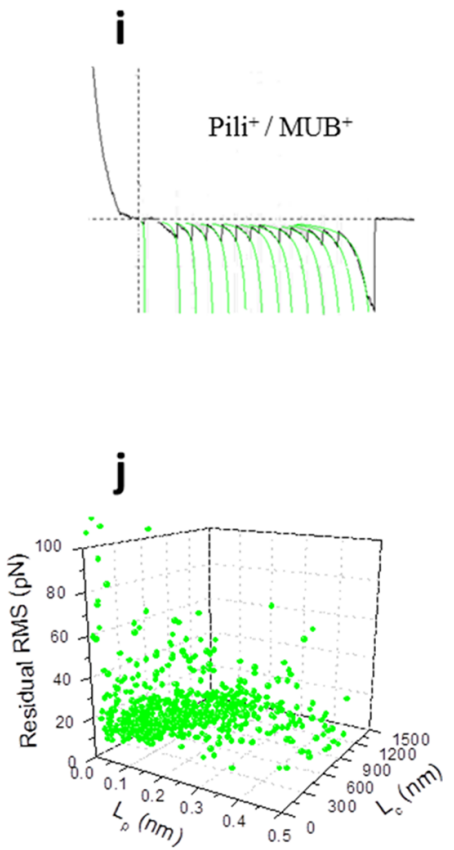

k

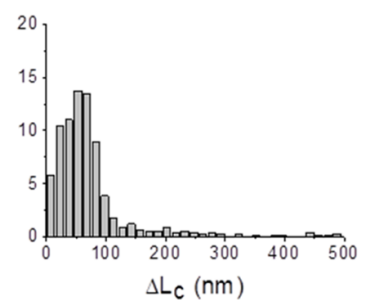

I

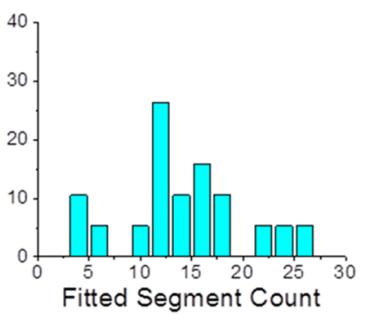

Figure 7. Physical analysis of various force signatures obtained in homotypic interactions for the vegetal isolate TIL448 and its derivatives. Typical unfolding curves from (a) Pil ${ }^{+} \mathrm{Mub}^{+}$and (e) $\mathrm{Pil}^{-} \mathrm{Mub}^{+}$(i) were fitted (green lines) with the WLC model. The fitting of 100 typical force curves was made, and the persistence length $\left(L_{\mathrm{p}}\right)$, contour length $\left(L_{\mathrm{c}}\right)$, and residual RMS are represented in (b), (f), and (j), respectively. (c, g, k) Distance between two consecutive rupture $\left(\Delta L_{\mathrm{c}}\right)$ and $(\mathrm{d}, \mathrm{h}, \mathrm{l})$ number of fitted segment per curve were analyzed.

antibodies to block the pili-pili interactions. Blocking pili-pili interactions with anti-YhgE antibodies resulted in a major reduction in adhesion forces, work, and distance rupture, thus showing the central role of the pili backbone (YhgE or PilB) in the homotypic interaction. The histograms of the blocking experiment in TIL448 (inset in Figure 5g) were similar to the interactions between $\mathrm{Pil}^{-} \mathrm{Mub}^{+}$TIL1289 cells (Figure 6b) or between $\mathrm{Pil}^{+} \mathrm{Mub}^{-}$TIL1290 and $\mathrm{Pil}^{-} \mathrm{Mub}^{+}$TIL1289 cells (Figure 6c). These observations demonstrated the implication of pili in homotypic cell-cell interactions in both laboratory and environmental strains. This was consistent with a previous report focused on the specific interactions between small adhesins along the pili of L. rhamnosus GG. ${ }^{14}$ Indeed, the authors in this study concluded that pili have multisite attachment and may have an important functional role in strengthening bacterial-bacterial interactions in the intestinal environment.

Another interesting parameter to better describe the role and function of pili homotypic interactions in cell-cell adhesion was the work of adhesion. The low values measured for control strains (less than $10 \times 10^{-18} \mathrm{~J}$ ) were in line with those found by Wang et al. $^{40}$ in control cells of Klebsiella pneumoniae, a Gram-negative bacteria, able to produce type 3 fimbriae (pililike). In this study, the adhesion work was $17 \times 10^{-18}$ to $19 \times$ $10^{-18} \mathrm{~J}$ for type 3 fimbriae-producing bacteria and $11 \times 10^{-18} \mathrm{~J}$ in the fimbriae-deficient strain. These values were in the same order of magnitude with those obtained here in the $\mathrm{Pil}^{-}, \mathrm{Pil}^{+}$, and $\mathrm{Pil}^{++}$strains $\left(7 \times 10^{-18} \pm 0.5 \mathrm{~J}, 15 \times 10^{-18} \pm 7\right.$ to $47 \times$ 
$10^{-18} \pm 15 \mathrm{~J}$, and up to $108 \times 10^{-18} \pm 27 \mathrm{~J}$, respectively) These congruent values illustrate favorable interactions between piliated cells and suggest that pili play a crucial role in cell-cell adhesion.This was consistent with previous observations of the tight aggregation phenotype of piliated $L$. lactis cells in liquid culture and with the structuration of piliated lactococci biofilms. ${ }^{16}$

The analysis of rupture event distances (Figure 2f,g and Figure 6d) showed the existence of short and long distances (up to $1500 \pm 95 \mathrm{~nm}$ ), which were coherent with the differences in pili length observed in the images presented in Figure 1 . The force signatures of pili from $L$. lactis strains were different from those described in L. rhamnosus GG, which showed sawtooth patterns composed of multiple small force peaks corresponding to the detachment of small adhesins along the pili. ${ }^{14}$ However, in the environmental $\mathrm{Pil}^{+} \mathrm{Mub}^{+}$TIL448 strain, no adhesins along the pili were found (Figures $5 \mathrm{~d}$ and $6 \mathrm{~d}$ ), but sawtooth patterns, due to the sliding of the pili on Mub proteins, were observed. These Mub proteins do not interact with each other (data not shown) but rather with other components of the cell surface or other surface proteins including pilins. The sliding of pili on Mub proteins was observed in retraction profiles and showed sawtooth patterns (Figures $5 \mathrm{f}$ and $6 \mathrm{f}$ ). This confirms the interaction between pili and Mub proteins. The interactions between pili and other surface proteins, such as milk proteins, were also demonstrated in L. rhamnosus $\mathrm{GG}^{14,41,42}$ and can be related to the better ability of these strains to form biofilms and interact with the proteins of the extracellular matrix.

The unfolding of both the pili-pili and pili-Mub intercations were described by the WLC model, which has often been used to analyze the unfolding of polypeptidic molecules. In this model, the unfolded macromolecule was considered as an irregular curved filament, which was linear at the scale of the persistence length $L_{\mathrm{p}}$. In addition to $L_{\mathrm{p}}$, other parameters such as contour length $L_{c}$ and $\Delta L_{c}$ were also extracted from the data. $L_{c}$ is the length of the fully extended molecule and $\Delta L_{c}$ is the distance in between each unfolding peak. $L_{\mathrm{p}}, L_{\mathrm{c}}$ and $\Delta L_{\mathrm{c}}$ were key parameters to describe and to understand the unfolding profiles that were obtained. The $L_{\mathrm{p}}$ values ranged from 0.05 to $0.6 \mathrm{~nm}$, which is close to the values found by $\mathrm{Lu}$ et al. on type IV pili in Pseudomonas aeruginosa PAO1 $\left(L_{\mathrm{p}}=\sim 0.8 \mathrm{~nm}\right)$ and to the the $L_{\mathrm{p}}$ values found by Fahs et al. ${ }^{43}$ ( 0.02 to $\left.0.7 \mathrm{~nm}\right)$ for the pili of L. rhamnosus GG. These two studies both used the same physical model as we did (WLC model). Fahs et al. ${ }^{43}$ and Guerin et al. ${ }^{42}$ explained that the low values of $L_{\mathrm{p}}$ were related to a weak potential of deformation. This means that pili were most probably rigid structures. Our data were in line with these interpretations that were also confirmed by Castelain et al. ${ }^{21}$ in their study of pili using optical tweezers. Moreover, Miller et al. ${ }^{44}$ also showed that the low value of the $L_{\mathrm{p}}$ meant that the globular subunit of PilB was not unfolded but that the pili polypeptidic chain was stretched. ${ }^{44}$ The variability of the $L_{c}$ values (between $50-1500$ $\mathrm{nm}$ ) showed that pili were made of macromolecules of different lengths. $L_{c}$ reflects the distance between two cells when the pili-pili interaction vanished. ${ }^{45}$ The differences in $L_{c}$ values can be explained by the variation in the number of polymerized monomers (100 to 200 monomers $^{16}$ ) that form the backbone of the pili. Our result for $L_{c}$ were comparable with the values obtained by Rheinlaender et al. ${ }^{46}$ with the pili of Corynebacterium diphtheria. Using the WLC model, these authors measured dispersed $L_{\mathcal{c}}$, ranging from 260 to $1590 \mathrm{~nm}$.
This could be due to random locations of the interactions in between pili resulting in unfoldings of random lengths. ${ }^{43}$ This interpretation was confirmed by our $\Delta L_{\mathrm{c}}$ analysis, which actually showed multimodal distribution (between 25-200 $\mathrm{nm}$, Figures $4 \mathrm{c}, \mathrm{g}$ and $7 \mathrm{c}$ ).

\section{CONCLUSIONS}

SCFS is a powerful technique to quantify the adhesion behavior between individual bacteria. Using this technique, we demonstrated in this work that in L. lactis, cell-cell adhesion abilities were driven by the presence of pili on their surface. In addition, both laboratory and environmental L. lactis showed a high adhesion force and work, in the case of piliated strains. This allowed us to demonstrate that pili-pili interactions were specific and homotypic. Based on the sawtooth signatures obtained when pili interact with Mub proteins, we assume that along the pili, there are several binding sites for proteins but there are no adhesins. This behavior of pili helped to understand the cell-cell adhesion step of biofilm formation and thus their influence on cell cohesion and biofilm structuring. From the nanomechanical point of view, the low $L_{\mathrm{p}}$ and variable $L_{\mathrm{c}}$ values, in addition to the observation of pili by TEM and AFM imaging, showed that pili of L. lactis were rigid and possessed a highly flexible polypeptide chain. The ability of LAB such as L. lactis cells to interact with each others through pili could be further used in medical applications such as mucosal vaccines or therapeutic drug delivery. In the industrial environment, the understanding of the pili-pili interactions and their role in the cell-cell adhesion step of biofilm formation could be useful to use positive biofilms in order to control proliferative undesired species.

\section{ASSOCIATED CONTENT}

\section{S1 Supporting Information}

The Supporting Information is available free of charge at https://pubs.acs.org/doi/10.1021/acsami.0c03069.

Heterotypic interactions between $\mathrm{Pil}^{+}$VE17173 and $\mathrm{Pil}^{-}$ VE17061; homotypic interactions between TIL1230 cells; interactions between $\mathrm{Pil}^{-}$VE17061 cells, cultures 2 and 3; homotypic interactions between $\mathrm{Pil}^{+} \mathrm{VE} 17173$ cells, cultures 2 and 3; homotypic interactions between $\mathrm{Pil}^{++}$VE17176 cells, cultures 2 and 3; homotypic interactions between $\mathrm{Pil}^{+} \mathrm{Mub}^{+}$TIL448 cells, cultures 2 and 3; homotypic interactions between $\mathrm{Pil}^{+} \mathrm{Mub}^{-}$ TIL1290 cells, cultures 2 and 3; homotypic interactions between $\mathrm{Pil}^{-} \mathrm{Mub}^{+}$TIL1289 cells, cultures 2 and 3; heterotypic interactions between $\mathrm{Pil}^{+} \mathrm{Mub}^{-}$TIL1290 and $\mathrm{Pil}^{-} \mathrm{Mub}^{+}$TIL1289 cells, cultures 2 and 3; analysis of various force signatures obtained in pili-pili interactions between the $\mathrm{Pil}^{++}$VE17176 cells;analysis of various force signatures obtained in pili-pili interactions in $\mathrm{Pil}^{+} \mathrm{Mub}^{+} \mathrm{TIL} 448$ strains; analysis of various force signatures of Mub proteins obtained in the interactions between the $\mathrm{Pil}^{-} \mathrm{Mub}^{+}$TIL1289 cells; andanalysis of various force signatures obtained in the interactions between the $\mathrm{Pil}^{+} \mathrm{Mub}^{-}$TIL1290 and the $\mathrm{Pil}^{-} \mathrm{Mub}^{+}$TIL1289 cells (PDF) 


\section{AUTHOR INFORMATION}

\section{Corresponding Author}

Etienne Dague - LAAS-CNRS, Universite de Toulouse, CNRS, 31000 Toulouse, France; 이이. orcid.org/0000-0003-3290-9166; Email: edague@laas.fr

\section{Authors}

Ibrahima Dramé - TBI, Université de Toulouse, INSA, INRAE CNRS, 31000 Toulouse, France; LAAS-CNRS, Université de Toulouse, CNRS, 31000 Toulouse, France

Cécile Formosa-Dague - TBI, Université de Toulouse, INSA, INRAE, CNRS, 31000 Toulouse, France; @ orcid.org/00000002-8627-3784

Christine Lafforgue - TBI, Universite de Toulouse, INSA, INRAE, CNRS, 31000 Toulouse, France

Marie-Pierre Chapot-Chartier - Universite Paris-Saclay, INRAE, AgroParisTech, Micalis Institute, 78350 Jouy-en-Josas, France

Jean-Christophe Piard - Universite Paris-Saclay, INRAE, AgroParisTech, Micalis Institute, 78350 Jouy-en-Josas, France

Mickaël Castelain - TBI, Université de Toulouse, INSA, INRAE, CNRS, 31000 Toulouse, France

Complete contact information is available at: https://pubs.acs.org/10.1021/acsami.0c03069

\section{Notes}

The authors declare no competing financial interest.

\section{ACKNOWLEDGMENTS}

E.D. and C.F.-D are researchers at Centre National de la Recherche Scientifique (CNRS). M.C. is a researcher at Institut National pour la Recherche Agronomique (INRA). C.L. is an Associate-Professor at INSA de Toulouse. I.D.'s PhD is funded by MESR (Doctoral School MEGEP). I.D. thanks the technical team at LAAS, particulary, Charline Blatché and Sandrine Souleille for their help in all experiments.

\section{REFERENCES}

(1) Drake, S. L.; Sandstedt, S. A.; Koomey, M. PilP, a Pilus Biogenesis Lipoprotein in Neisseria Gonorrhoeae, Affects Expression of PilQ as a High-Molecular-Mass Multimer. Mol. Microbiol. 1997, 23, 657-668.

(2) Andersson, M.; Fällman, E.; Uhlin, B. E.; Axner, O. Dynamic Force Spectroscopy of E. Coli P Pili. Biophys. J. 2006, 91, 2717-2725.

(3) Lu, S.; Giuliani, M.; Harvey, H.; Burrows, L. L.; Wickham, R. A.; Dutcher, J. R. Nanoscale Pulling of Type IV Pili Reveals Their Flexibility and Adhesion to Surfaces over Extended Lengths of the Pili. Biophys. J. 2015, 108, 2865-2875.

(4) Craig, L.; Pique, M. E.; Tainer, J. A. Type IV Pilus Structure and Bacterial Pathogenicity. Nat. Rev. Microbiol. 2004, 2, 363-378.

(5) Telford, J. L.; Barocchi, M. A.; Margarit, I.; Rappuoli, R.; Grandi, G. Pili in Gram-Positive Pathogens. Nat. Rev. Microbiol. 2006, 4, 509519.

(6) Murphy, E. C.; Janulczyk, R.; Karlsson, C.; Mörgelin, M.; Frick, I.-M. Identification of Pili on the Surface of Finegoldia Magna-a Gram-Positive Anaerobic Cocci. Anaerobe 2014, 27, 40-49.

(7) Krishnan, V. Pilins in Gram-Positive Bacteria: A Structural Perspective. IUBMB Life 2015, 67, 533-543.

(8) Yanagawa, R.; Shinagawa, M. Characteristics of Corynebacterium Renale Phage. Jpn. J. Vet. Res. 1968, 16, 137-143.

(9) Ton-That, H.; Schneewind, O. Assembly of Pili on the Surface of Corynebacterium Diphtheriae. Mol. Microbiol. 2003, 50, 1429-1438.

(10) Hendrickx, A. P. A.; Budzik, J. M.; Oh, S.-Y.; Schneewind, O. Architects at the Bacterial Surface - Sortases and the Assembly of Pili with Isopeptide Bonds. Nat. Rev. Microbiol. 2011, 9, 166-176.
(11) Wang, Y.; Wang, J.; Dai, W. Use of GFP to Trace the Colonization of Lactococcus Lactis WH-C1 in the Gastrointestinal Tract of Mice. J. Microbiol. Methods 2011, 86, 390-392.

(12) Lebeer, S.; Claes, I.; Tytgat, H. L. P.; Verhoeven, T. L. A.; Marien, E.; von Ossowski, I.; Reunanen, J.; Palva, A.; de Vos, W. M.; de Keersmaecker, S. C. J.; Vanderleyden, J. Functional Analysis of Lactobacillus Rhamnosus GG Pili in Relation to Adhesion and Immunomodulatory Interactions with Intestinal Epithelial Cells. Appl. Environ. Microbiol. 2012, 78, 185-193.

(13) Kankainen, M.; Paulin, L.; Tynkkynen, S.; von Ossowski, I.; Reunanen, J.; Partanen, P.; Satokari, R.; Vesterlund, S.; Hendrickx, A. P. A.; Lebeer, S.; De Keersmaecker, S. C. J.; Vanderleyden, J.; Hämäläinen, T.; Laukkanen, S.; Salovuori, N.; Ritari, J.; Alatalo, E.; Korpela, R.; Mattila-Sandholm, T.; Lassig, A.; Hatakka, K.; Kinnunen, K. T.; Karjalainen, H.; Saxelin, M.; Laakso, K.; Surakka, A.; Palva, A.; Salusjärvi, T.; Auvinen, P.; de Vos, W. M. Comparative Genomic Analysis of Lactobacillus Rhamnosus GG Reveals Pili Containing a Human- Mucus Binding Protein. Proc. Natl. Acad. Sci. U. S. A. 2009, 106, 17193-17198.

(14) Tripathi, P.; Beaussart, A.; Alsteens, D.; Dupres, V.; Claes, I.; von Ossowski, I.; de Vos, W. M.; Palva, A.; Lebeer, S.; Vanderleyden, J.; Dufrêne, Y. F. Adhesion and Nanomechanics of Pili from the Probiotic Lactobacillus Rhamnosus GG. ACS Nano 2013, 7, 36853697.

(15) Turroni, F.; Serafini, F.; Mangifesta, M.; Arioli, S.; Mora, D.; van Sinderen, D.; Ventura, M. Expression of Sortase-Dependent Pili of Bifidobacterium Bifidum PRL2010 in Response to Environmental Gut Conditions. FEMS Microbiol. Lett. 2014, 357, 23-33.

(16) Oxaran, V.; Ledue-Clier, F.; Dieye, Y.; Herry, J.-M.; Péchoux, C.; Meylheuc, T.; Briandet, R.; Juillard, V.; Piard, J.-C. Pilus Biogenesis in Lactococcus Lactis: Molecular Characterization and Role in Aggregation and Biofilm Formation. PLoS One 2012, 7, No. e50989.

(17) Madsen, K.; Cornish, A.; Soper, P.; McKaigney, C.; Jijon, H.; Yachimec, C.; Doyle, J.; Jewell, L.; De Simone, C. Probiotic Bacteria Enhance Murine and Human Intestinal Epithelial Barrier Function. Gastroenterology 2001, 121, 580-591.

(18) Wells, J. Mucosal Vaccination and Therapy with Genetically Modified Lactic Acid Bacteria. Annu. Rev. Food Sci. Technol. 2011, 2, 423-445.

(19) Veiga, P.; Pons, N.; Agrawal, A.; Oozeer, R.; Guyonnet, D.; Brazeilles, R.; Faurie, J.-M.; van Hylckama Vlieg, J. E. T.; Houghton, L. A.; Whorwell, P. J.; Ehrlich, S. D.; Kennedy, S. P. Changes of the Human Gut Microbiome Induced by a Fermented Milk Product. Sci. Rep. 2014, 4, 6328.

(20) Castelain, M.; Duviau, M.-P.; Oxaran, V.; Schmitz, P.; CocaignBousquet, M.; Loubière, P.; Piard, J.-C.; Mercier-Bonin, M. Oligomerized Backbone Pilin Helps Piliated Lactococcus Lactis to Withstand Shear Flow. Biofouling 2016, 32, 911-923.

(21) Castelain, M.; Duviau, M.-P.; Canette, A.; Schmitz, P.; Loubière, P.; Cocaign-Bousquet, M.; Piard, J.-C.; Mercier-Bonin, M. The Nanomechanical Properties of Lactococcus Lactis Pili Are Conditioned by the Polymerized Backbone Pilin. PLoS One 2016, 11, No. e0152053.

(22) Meyrand, M.; Guillot, A.; Goin, M.; Furlan, S.; Armalyte, J.; Kulakauskas, S.; Cortes-Perez, N. G.; Thomas, G.; Chat, S.; Péchoux, C.; Dupres, V.; Hols, P.; Dufrêne, Y. F.; Trugnan, G.; ChapotChartier, M.-P. Surface Proteome Analysis of a Natural Isolate of Lactococcus Lactis Reveals the Presence of Pili Able to Bind Human Intestinal Epithelial Cells. Mol. Cell. Proteomics 2013, 12, 3935-3947. (23) Le, D. T. L.; Tran, T.-L.; Duviau, M.-P.; Meyrand, M.; Guérardel, Y.; Castelain, M.; Loubière, P.; Chapot-Chartier, M.-P.; Dague, E.; Mercier-Bonin, M. Unraveling the Role of Surface MucusBinding Protein and Pili in Muco-Adhesion of Lactococcus Lactis. PLoS One 2013, 8, No. e79850.

(24) Florin, E. L.; Moy, V. T.; Gaub, H. E. Adhesion Forces between Individual Ligand-Receptor Pairs. Science 1994, 264, 415-417. 
(25) Bowen, W. R.; Lovitt, R. W.; Wright, C. J. Atomic Force Microscopy Study of the Adhesion of Saccharomyces Cerevisiae. J. Colloid Interface Sci. 2001, 237, 54-61.

(26) Dague, E.; Le, D. T. L.; Zanna, S.; Marcus, P.; Loubière, P.; Mercier-Bonin, M. Probing In Vitro Interactions between Lactococcus Lactis and Mucins Using AFM. Langmuir 2010, 26, 1101011017.

(27) Boekhorst, J.; Helmer, Q.; Kleerebezem, M.; Siezen, R. J. Comparative Analysis of Proteins with a Mucus-Binding Domain Found Exclusively in Lactic Acid Bacteria. Microbiology 2006, 152, 273-280.

(28) Juge, N. Microbial Adhesins to Gastrointestinal Mucus. Trends Microbiol. 2012, 20, 30-39.

(29) Mercier-Bonin, M.; Chapot-Chartier, M.-P. Surface Proteins of Lactococcus Lactis: Bacterial Resources for Muco-Adhesion in the Gastrointestinal Tract. Front. Microbiol. 2017, 8, 2247.

(30) Otto, M. Staphylococcal Biofilms. Curr. Top. Microbiol. Immunol. 2008, 322, 207-228.

(31) Hutter, J. L.; Bechhoefer, J. Calibration of Atomic-force Microscope Tips. Rev. Sci. Instrum. 1993, 64, 1868-1873.

(32) Benoit, M.; Gabriel, D.; Gerisch, G.; Gaub, H. E. Discrete Interactions in Cell Adhesion Measured by Single-Molecule Force Spectroscopy. Nat. Cell Biol. 2000, 2, 313-317.

(33) Beaussart, A.; Herman, P.; El-Kirat-Chatel, S.; Lipke, P. N.; Kucharíková, S.; Van Dijck, P.; Dufrêne, Y. F. Single-Cell Force Spectroscopy of the Medically Important Staphylococcus Epidermidis-Candida Albicans Interaction. Nanoscale 2013, 5, 10894-10900.

(34) Bustamante, C.; Marko, J. F.; Siggia, E. D.; Smith, S. Entropic Elasticity of Lambda-Phage DNA. Science 1994, 265, 1599-1600.

(35) Janshoff, A.; Neitzert, M.; Oberdörfer, Y.; Fuchs, H. Force Spectroscopy of Molecular Systems-Single Molecule Spectroscopy of Polymers and Biomolecules. Angewandte Chemie International Edition 2000, 39, 3212-3237.

(36) Francius, G.; Lebeer, S.; Alsteens, D.; Wildling, L.; Gruber, H. J.; Hols, P.; De Keersmaecker, S.; Vanderleyden, J.; Dufrêne, Y. F. Detection, Localization, and Conformational Analysis of Single Polysaccharide Molecules on Live Bacteria. ACS Nano 2008, 2, 1921-1929.

(37) Kline, K. A.; Kau, A. L.; Chen, S. L.; Lim, A.; Pinkner, J. S.; Rosch, J.; Nallapareddy, S. R.; Murray, B. E.; Henriques-Normark, B.; Beatty, W.; Caparon, M. G.; Hultgren, S. J. Mechanism for Sortase Localization and the Role of Sortase Localization in Efficient Pilus Assembly in Enterococcus Faecalis. J. Bacteriol. 2009, 191, 32373247.

(38) de Weirdt, R.; de Wiele, T. V. Micromanagement in the Gut: Microenvironmental Factors Govern Colon Mucosal Biofilm Structure and Functionality. npj Biofilms Microbiomes 2015, 1, 15026. (39) Piard, J.-C.; Briandet, R. Lactic Acid Bacteria Biofilms. In Biotechnology of Lactic Acid Bacteria; John Wiley \& Sons, Ltd, 2015; pp 341-361, DOI: 10.1002/9781118868386.ch20.

(40) Wang, H.; Wilksch, J. J.; Chen, L.; Tan, J. W. H.; Strugnell, R. A.; Gee, M. L. Influence of Fimbriae on Bacterial Adhesion and Viscoelasticity and Correlations of the Two Properties with Biofilm Formation. Langmuir 2016, 33, 100-106.

(41) Burgain, J.; Scher, J.; Lebeer, S.; Vanderleyden, J.; CailliezGrimal, C.; Corgneau, M.; Francius, G.; Gaiani, C. Significance of Bacterial Surface Molecules Interactions with Milk Proteins to Enhance Microencapsulation of Lactobacillus Rhamnosus GG. Food Hydrocolloids 2014, 41, 60-70.

(42) Guerin, J.; Bacharouche, J.; Burgain, J.; Lebeer, S.; Francius, G.; Borges, F.; Scher, J.; Gaiani, C. Pili of Lactobacillus rhamnosus GG Mediate Interaction with $\beta$-Lactoglobulin. Food hydrocolloids 2016, 58, 35-41.

(43) Fahs, A.; Quilès, F.; Jamal, D.; Humbert, F.; Francius, G. In Situ Analysis of Bacterial Extracellular Polymeric Substances from a Pseudomonas Fluorescens Biofilm by Combined Vibrational and Single Molecule Force Spectroscopies. J. Phys. Chem. B 2014, 118, 6702-6713.
(44) Miller, E.; Garcia, T.; Hultgren, S.; Oberhauser, A. F. The Mechanical Properties of E. Coli Type 1 Pili Measured by Atomic Force Microscopy Techniques. Biophys. J. 2006, 91, 3848-3856.

(45) Huang, Q.; Wu, H.; Cai, P.; Fein, J. B.; Chen, W. Atomic Force Microscopy Measurements of Bacterial Adhesion and Biofilm Formation onto Clay-Sized Particles. Sci. Rep. 2015, 5, 16857.

(46) Rheinlaender, J.; Gräbner, A.; Ott, L.; Burkovski, A.; Schäffer, T. E. Contour and Persistence Length of Corynebacterium Diphtheriae Pili by Atomic Force Microscopy. Eur. Biophys. J. 2012, $41,561-570$. 